\title{
The roles of the formal and informal sectors in the provision of
}

effective science education

Susan M. Stocklmayer

The Australian National University, Canberra, Australia

Léonie J. Rennie

Curtin University of Technology, Western Australia

John K. Gilbert

The University of Reading and King's College London, UK

Associate Professor Susan M. Stocklmayer.

The Centre for the Public Awareness of Science, Building 38a,

The Australian National University,

Canberra,

ACT 0200, Australia.

Email sue.stocklmayer@anu.edu.au

Professor Léonie J. Rennie

Office of Research and Development

Curtin University of Technology

GPO Box U1987

Perth WA 6845 Australia.

Email: 1.rennie@curtin.edu.au

Professor Emeritus John K. Gilbert, Institute of Education,

The University of Reading,

Bulmershe Court,

Reading RG6 1HY,

United Kingdom.

Email: john.k.gilbert@btinternet.com

Corresponding Author, Léonie J. Rennie

DOI: 10.1080/03057260903562284 


\begin{abstract}
For many years, formal school science education has been criticised by students, teachers, parents and employers, throughout the world. This article presents an argument that a greater collaboration between the formal and the informal sector could address some of these criticisms. The causes for concern about formal science education are summarised and the major approaches being taken to address them are outlined. The contributions that the informal sector currently makes to science education are identified. It is suggested that the provision of an effective science education entails an enhanced complementarity between the two sectors. Finally, there is a brief discussion of the collaboration and communication still needed if this is to be effective.
\end{abstract}

Keywords: informal education, science curriculum, community involvement, scientific literacy, attitudes to science

\title{
Introduction
}

In this article we argue for greater complementarity between formal school science education and the opportunities offered for science learning that are available outside of school, in what we will call the "informal sector". We recognise that, within each sector, institutions and other providers operate under varied systems of governance, and have varied raisons d'être. However, a desired outcome of both is a citizenry that is educated with respect to science and, despite the differences between them, we believe that greater synergy between the two sectors can result in an enhanced science education for students at school.

In the first section of the article we explore the current state of science education, identify the nature of the criticisms it faces and draw out the key questions that need to be answered if the informal sector is to play a more complementary role. In the second section we describe the nature of the informal sector and how engagement and learning is facilitated within it, before drawing together the threads of these two major sections in order to establish what we perceive as the complementarity between them. In the final section we suggest ways that this can be exploited, highlighting especially the contribution that the informal sector can make to in-school learning. 


\section{The nature of current formal science education}

For many years now, the state of science education has been critiqued in terms of its goals, its practice and its outcomes. For much of the previous century there were voices calling for reform (see, for example, American Association for the Advancement of Science, 1989; Black, 1995 and other articles in volume 26 of this journal; Bybee, 1985; Bybee \& DeBoer, 1994; Dewey, 1902; Millar \& Osborne, 1998), but these calls became more widespread from the time that the public understanding of science movement came to the fore in the late 1980s (for example, Durant, Evans, \& Thomas, 1989). A central issue is: how can school science education both prepare some students to go on to careers in science and technology and prepare all students to be responsible, scientifically literate, citizens? (Fensham, 1985; Millar, 1996).

In the following discussion, we refer to science education at the lower secondary (junior high) school level because it appears that these are the most problematic years. This is the time that students begin to choose career options and it is here that the disengagement with science is most clearly evident. Also, our comments refer primarily to developed countries, for those who attend secondary school in developing countries regard the study of science as enhancing career prospects and hence economic status (Sjøberg and Schreiner, 2005).

The goals of formal science education have been debated and redefined many times (DeBoer, 2000; Fensham, 1992). For example, relatively recently Hodson (1998) wrote about the ideals of a tripartite view of science education.

learning science - acquiring and developing conceptual and theoretical knowledge; learning about science - developing an understanding of the nature and methods of science, an appreciation of its history and development, and an awareness of the complex interactions among science, technology, society and environment; and doing science - engaging in and developing expertise in scientific enquiry and problem solving. (p. 191) [italics in original] 
He also remarked, however, that "many of the messages about science that we build into the curriculum...are still locked in the mind set of the 1960s and early 1970s” (p. 192).

In a recent UNESCO commissioned document written after the 2007 World Conference on Science and Technology Education, Fensham (2008) argued that

Getting the balance right between the purposes of enthusing enough students to go on to scientific and technological careers and of giving all students an interest in, and enough knowledge of S\&T [science and technology] to appreciate the importance of science and technology in society, is perhaps the major S\&T educational issue facing all countries today. (p. 15)

Defining appropriate goals is the first recommendation of the UNESCO policy document, with accompanying curriculum changes being required to foster these goals. The problem is that "secondary science teachers will need considerable professional development help in reconceptualising this restructuring of the curriculum” (Fensham, 2008, p. 16). This is not a new message (Goodrum, Hackling, \& Rennie, 2001; Millar \& Osborne, 1998). Science teachers’ difficulty in embracing change has been a major factor in the retention of traditional curricula. There is much literature on this topic (see, for example, Aikenhead, 2006, for a summary). Thus Fensham (2008) acknowledged that "quality science learning time, albeit less [of it], is preferable to the damage done by under-equipped science teachers” (p. 18). Although the plea for adequate professional development has been made many times, it has proved beyond the capabilities of successive governments in many countries to provide it. Further, there is constant attrition of younger teachers, as they become disillusioned with the systems in place and their inability to effect change, whilst becoming increasingly aware of their value on the wider employment market. A survey by the Australian Council of Deans of Science (Harris, Jensz, \& Baldwin, 2005), for example, found that almost $40 \%$ of early career teachers of secondary science were uncertain they would still be teaching in five years time. 
Science students, too, are often disillusioned. It is now well established that, for many years, the proportion of voluntary school enrolments in science (i.e. beyond any compulsory stage) has been declining in most Western countries (Ainley, Kos, \& Nicholas, 2008; Dekkers \& de Laeter, 2001; OECD, 2006; Osborne \& Collins, 2000; Porter \& Parvin, 2009; Welch \& Walberg, 1967). In particular, the physical and earth sciences have suffered from this trend. At the heart of the decline is the way in which science is presented in school at junior high school level. Aikenhead (2006) argued that "the most cogent factor acting against (post-compulsory) enrolment was found to be the culture of school science itself” (p. 26). Other reasons why students are not engaged with school science include cultural alienation, a phrase embracing lower socioeconomic, gender, minority and indigenous groups. The nature of the curriculum itself has been termed dishonest (Aikenhead, 2006), even mythical (Hodson, 1998), because it portrays a science that is not as practised.

What is being done to address these issues? The report of the European Commission (2007) views the resurgence of science education as dependent on more inquiry-based teaching and, significantly, increased opportunities for cooperation between the formal and informal sectors. In surveys conducted by the Relevance of Science Education (ROSE) project (Sjøberg \& Schreiner, 2005), students themselves in many countries have expressed a need for more relevance. The ROSE project measured high school students' attitudes to science and found that the majority were indifferent to science both in school and as a future career. There were stark differences between developed and developing countries, however, with students in developing countries much more positive about the role of science in society and a desire for employment in that area (Sjøberg \& Schreiner, 2005). In developed countries, parents, as well as students, are dissatisfied (Jenkins \& Pell, 2006; Osborne 
\& Collins, 2000). The key issue is that "It is urgent that educational policy makers address the lack of engagement that so many students experience in school science and technology education” (Fensham, 2008, p. 20).

Jenkins (1999) argued the importance of recognizing that "the raison d'être of a science curriculum is science itself” (p. 707). He continued, "any characterisation of the scientific endeavour....must take into account that science is now intimately related to production and profit” (p. 707). The implication is that the science curriculum must address the social and political pressures that shape its practice. Jenkins cited "transdisciplinarity, new criteria for quality control and the generation of knowledge within the context of its application” as characterising a new framework for science and, by extension, for science education.

School science education needs to respond to this changed social context and to help prepare young people to contribute as citizens in shaping the world in which they will live. This means constructing science curricula that enable young people to engage [reflexively] with science-related issues that are likely to be of interest and concern to them. (p. 707)

So then, in summary, there have been calls for science education to be more relevant to young people's lives, to more faithfully reflect the conduct of science itself, and to be taught through inquiry.

There have been many attempts to change the way in which science is taught, endeavouring to increase the quality, or meaningfulness, of students' learning (Aikenhead, 2006; Fensham, 1998). None of these efforts has so far been effective in initiating sustained change on a wide scale. This is despite isolated stories of success in curriculum change, such as those described in Black and Atkin (1996), who point out that every participating country in their study was dissatisfied with science education and was trying to find solutions, but that these had to occur within the needs and cultural contexts of the countries concerned. This search for meaning and 
relevance should be a powerful driver for change, but it is not happening on a wide scale.

Although these problems are not new, attempts to address the issues that they raise have generally been unsuccessful. For example, Kahle (2007) examined three waves of large-scale attempts to radically revise the whole system of science curriculum in the United States, charting their progress from their inception to their final outcomes. Her analysis confirmed that the current challenges to improving school science are immense: not only does change take considerable time, and requires both top-down and bottom-up approaches, but it must be supported by the politics of the day. Further, ways have to be found to make new curricula available to all students. This has to take place against a background of gender issues, of "border crossing” arising from the increasingly diverse cultural backgrounds in many student populations (Aikenhead, 2006), and the very diverse economic circumstances of schools, students, and their families (Berliner, 2009).

To coin a metaphor, the ship of traditional science curriculum is floundering because of lack of engagement by students. The holes in the hull have all been identified many times: lack of relevance, variable teacher competence, discrimination and exclusion, inappropriate images of science, outdated content..., the list is long. Patching up the holes has been going on for decades. Efforts to refloat the old tub with some major refurbishments, to recaulk the hull, replace the navigation instruments, refresh the cargo, retrain the crew, are certainly going on throughout the world. Yet the nature of governance of school science education inhibits the direction and pace of change, for what is to be provided has to be available to all. It is also heavily influenced by what has "always" been done. History acts as a powerful seaanchor. 


\section{Why the curriculum is as it is}

Since the establishment of science in schools, initially in UK, USA, and Germany, from the 1860s onwards, the purpose of the science curriculum has been predominately to screen students and prepare those with the most knowledge of school science for the study of the sciences or engineering at university level (Aikenhead, 2006, pp. 13-15). Historically, there have been attempts to address matters of the practical utility of science and its implications for everyday life in the curriculum (Donnelly, 2002), but these have proved problematic (see, for example, Fensham, 1998). Yet it is the large majority of students who do not aspire to a science-related career who would benefit most from a science education with the purpose of preparing them to cope with science in lives that are not primarily focused on science and technology. More recently, the relationships between the two purposes for science education have become conflated under the slogan terms of "science for all” or "science literacy".

"Science literacy" is a broad-brush concept that has been the subject of many interpretations (Laugksch, 2000). Essentially, a person who is scientifically literate not only knows about science and its technological and societal implications, but can use scientific evidence in everyday decision-making. In a seminal review of 31 studies relating to science literacy, Ryder (2001) concluded that knowledge about the epistemology of science is important and "being more informed about 'the true nature of science' is likely to enable individuals to engage more effectively with science” (pp. 37-38). Compulsory curricula in schools, however, “must serve at least two additional aims: science for cultural purposes and science as a preparation for future science professionals” (p. 38). 
Roberts (2007) has coalesced these interpretations into two Visions of scientific literacy. "Vision I", he argued, is obtained by "looking inwards at the canon of orthodox natural science, that is, at the products and processes of science itself” (p. 730). "Vision II” is obtained by looking outwards, considering "the character of situations with a scientific component, situations that students are likely to encounter as citizens” (p. 730). Importantly, Roberts pointed out, “Vision II subsumes Vision I, but the converse is not necessarily so" (p. 768).

The traditional science curriculum is firmly rooted in Vision I. Even within this Vision, however, the ideal of looking at products and processes can differ greatly from how science is actually conducted today: it lacks "authenticity” (Hodson, 1998). Attempts have been and are being made to elucidate Vision II within specific national contexts, for example in the USA (National Research Council, 1996), the UK (Millar \& Osborne, 1998; Osborne, Duschl, \& Fairbrother, 2002; Twenty First Century Science, 2008), and Australia (Fensham, 1998). In the UK, for example, Vision II appears to dominate current discussion, with a "scientifically literate" person being able to

- $\quad$ appreciate and understand the impact of science and technology on everyday life;

- take informed decisions about things that involve science, such as health, diet, use of energy resources;

- read and understand the essential points of media reports about matters that involve science;

- reflect critically on the information included in, and (often more important) omitted from such reports;

- take part confidently in discussions with others about issues involving science (Twenty First Century Science, 2008).

\section{Issues for effective reform}

Moving towards a science curriculum that reflects the kind of scientific literacy described by Vision II requires that the problems we have identified in the first part of this discussion continue to be tackled. Essentially, these revolve around 
increasing student engagement, findings ways to clearly demonstrate the relevance of the content, promoting inquiry-based learning, providing for transdisciplinary contexts and for cultural and social differences. It is also important to reflect the nature of science in a modern context as well as promote understanding of its historical context and development. If all this were not enough, the need for continuing teacher professional development underpins all efforts to change the nature of curricula, particularly when cross-disciplinary contexts are incorporated into science. Teachers have little time to research and explore such content and they find innovative practice difficult to implement (Davis, 2003).

We have observed, from visits to many (but, of course, not all) classrooms, that transmissive teaching and passive, behaviourist learning assuming no active mental engagement are commonplace. The teacher dominates proceedings in the classroom, either by making an exposition that occupies most of the time available or by constantly referring to a textbook. The students listen passively, copying material into their notebooks, with their contributions being restricted to answering questions posed by the teacher. Such teaching approaches are readily accepted only by pupils who are strongly motivated towards science and who have few problems in understanding abstract concepts. Porter and Parvin (2009) reported that a poll of 4000 British students aged between 9 and 14 years revealed that "students felt science lessons become less inspiring as they get older... the most popular part of the science curriculum is the practical work, while there is far less enthusiasm for written work" (p. 12). The relative popularity of practical work, also noted by Barmby, Kind, and Jones (2008), highlights the need for active student participation in the classroom. Historically, science curricula have largely consisted, at worst, of isolated facts and, at best, of concepts that unite sets of facts. White (1994) has undertaken an 
analysis of this content. The concepts are often of a high level of abstraction (for example, those in Newtonian physics), and can appear unrelated to everyday experiences. Others, being at first sight more obviously useful (for example, “force”, “light”, and "heat”) are often taught without regard to their scope and limitations, so that students (and sometimes teachers) carry over their prior understandings (otherwise called alternative conceptions or misconceptions) leading to confused learning (Gilbert, Osborne, \& Fensham, 1982, and many others). Finally, these concepts are often taught in isolation from the processes of scientific enquiry that gave rise to them. Textbooks often compound the problem.

Incorporating those topics that are the most significant in science at the present time and, in anticipation, the future, will be important frames for some of these concepts. The use of "contexts" as a basis for topic, and therefore concept, choice (Gilbert, 2006; Pilot \& Bulte, 2006) circumnavigates the demarcation disputes between the separate sciences and enables some of these issues to be addressed.

An important aspect of science curricula, and one that is receiving increased emphasis in curriculum documents (see, for example, Twenty First Century Science, 2008) is an understanding of the Nature of Science (NOS). Lederman (2007) stated that "NOS typically refers to the epistemology of science, science as a way of knowing, or the values and beliefs inherent to scientific knowledge and its development” (p. 833). Whatever might have been taught about NOS - and there is a broad consensus about this (Lederman, 2007, pp. 833-835) - the outcomes of 50 years of effort can be generalised as:

- K-12 students do not typically possess “adequate” conceptions of NOS.

- K-12 teachers do not typically possess "adequate” conceptions of NOS.

- Conceptions of NOS are best learned through explicit, reflective instruction as opposed to implicitly through experiences with simply "doing science”.

- Teachers' conceptions of NOS are not automatically and necessarily translated into classroom practice. 
- Teachers do not regard NOS as an instructional outcome of equal status with that of "traditional" subject matter outcomes. (Lederman, 2007, p. 869)

Thus any attempts to include NOS in the curriculum are likely to be impeded by classroom tradition and practice. Coupling direct teaching of NOS with the design and conduct of genuine enquiries in science (Hodson, 1990), may be the most effective approach to dealing with it in the science curriculum (Lederman, 2007).

Whilst the degree of emphasis varies from country to country, the curricula for all school subjects are decided upon in a top-down model, with central government employees and consultants evidently paying little heed to the ideas of other “stakeholders”, for example, teachers, parents, social pressure groups (Aikenhead, 2006, pp. 206-209). The consequences, according to Black and Atkin (1996, pp. 3236), are that new ideas about NOS are not accommodated, and newer approaches to teaching and learning are not adopted. Further, the relationships of science to other subjects, for example, mathematics and First Language, are overlooked (Venville, Wallace, Rennie, \& Malone, 2002).

We suggest that courses might be more motivating to students if they were based on ideas drawn from a wide variety of stakeholders, including the students themselves, and were designed to give teachers and students greater flexibility in working with issues of local relevance.

\section{Finding solutions}

In the preceding section, we have examined the problems in science curricula and some key issues in the way that science is commonly presented to students in the classroom. In particular, the need to re-engage students, especially at the lower secondary level, is paramount. If Vision II courses are to be influential in school science education, the formal sector will need considerable help. If the informal sector 
is to augment what the formal sector provides, then it must address the current weaknesses in the latter. Building on our analyses of the problems, we believe there are a minimum of the questions that must be asked and answered if progress is to be made in improving current science education. These relate to how to clearly demonstrate the relevance of the content and thereby increase student engagement; how to promote inquiry-based learning; how to provide for cross-disciplinary contexts and for cultural and social differences; how to deal with NOS in a modern, social and historical context. In addition, the problems of teacher professional development must be addressed.

- How can the key concepts and ideas needed to move towards a Vision II science curriculum be identified and presented to students in a more relevant and engaging manner?

- How can learning of these concepts effectively be facilitated?

- How can more active student participation in approaches to learning be facilitated?

- How can Nature of Science be addressed and its key skills effectively developed?

- What modes of presentation of ideas are best suited to what concepts and which students?

- How can the views and specialised knowledge of a wide variety of stakeholders be incorporated in the design of science curricula?

These are not easy questions to address, otherwise answers would have been found and implemented long before now. While central agencies responsible for curriculum development and implementation continue their efforts to improve science education, we propose that the informal sector could be called upon to contribute.

Taking all these challenges/opportunities into account, we therefore ask what the informal sector can do to:

- increase the appropriateness, that is, the meaningfulness and relevance, of the formal science curriculum, especially with respect to current and future issues,

- improve the engagement of students with the formal school science curriculum, especially through inquiry learning and cross-disciplinary contexts,

- contribute to teacher professional development,

and, perhaps most importantly, 
- how can the complementary contributions of the informal sector and the formal sector provide an effective science education for all?

\section{Science education in the informal sector}

Science learning occurs outside of school in a range of environments characterised as the informal sector. According to Crane, Nicholson, Chen and Bitgood (1994):

Informal science learning refers to activities that occur outside the school setting, are not developed primarily for school use, are not developed to be part of an ongoing school curriculum, and are characterized as voluntary as opposed to mandatory participation as part of a credited school experience. (p. 3)

In 2003, the Informal Science Education Ad Hoc Committee of the Board of the National Association for Research in Science Teaching (NARST) published a Policy

Statement about learning science in informal contexts. The Committee agreed that:

Learning rarely if ever occurs and develops from a single experience. Rather, learning in general, and science learning in particular, is cumulative, emerging over time through myriad human experiences, including but not limited to experiences in museums and schools; while watching television, reading newspapers and books, conversing with friends and family; and increasingly frequently, through interactions with the Internet. The experiences children and adults have in these various situations dynamically interact to influence the ways individuals construct scientific knowledge, attitudes, behaviors, and understanding. In this view, learning is an organic, dynamic, never-ending, and holistic phenomenon of constructing personal meaning. This broad view of learning recognizes that much of what people come to know about the world, including the world of science content and process, derives from real-world experiences within a diversity of appropriate physical and social contexts, motivated by an intrinsic desire to learn.

(Dierking, Falk, Rennie, Anderson, \& Ellenbogen, 2003, p. 109)

We thus need to embrace three important characteristics of learning: it is a

personal process, it is contextualized, and it takes time. Rennie (2007) pointed out that

"some educational and psychological theories advanced about learning have not

recognized these characteristics, but it turns out that these aspects are especially

significant to understanding and investigating learning outside of school” (p. 128).

The issue of ownership of knowledge is also particularly relevant when considering the intersection of learning in formal and informal contexts. Paechter (1998), whilst emphasising strongly that power is conferred by the high status of school knowledge, disagreed with the many authors who contrast this kind of powerful knowledge with “owned knowledge" - that is, knowledge gained outside of school (p. 170). 
Owned knowledge is not simply something that is learned well, it is that which contains within it the potential for effective individual and group action. It positions its possessor as an acting subject, able to use his or her knowledge in a dynamic way. The question now arises, how can we bring about a situation in which owned knowledge is given sufficient legitimacy in the schooling system for ownership to continue within the classroom? (p. 174)

In the following sections, we analyse the potential and actual contribution of learning science in the informal sector within a framework of questions.

\section{What is informal learning?}

Informal learning has been described by many authors, but these descriptions place more focus on the context of learning rather the nature of learning. For example, Wellington (1990, p. 248) categorised formal and informal learning as shown in Table 1 , and these differences tend to reflect in-school and out-of-school contexts.

Insert Table 1 about here

Martin (2004, p. S75) took a different view. She divided formal and informal learning along similar lines to those adopted by Wellington, but distinguished kinds of learning in culturally specific contexts, as shown in Table 2.

Insert Table 2 about here

Others, such as Eraut (2004) and Malcolm, Hodkinson and Colley (2003), examined informal learning in the workplace. Eraut (2004, p. 250) produced a typology which also considered the cumulative nature of learning. Malcolm et al. (2003), having examined ten such analyses, came to the conclusion that "it is not possible to clearly define separate ideal-types of formal and informal learning, which bear any relation to actual learning experiences” (p. 314). They listed 20 criteria 
drawn from the literature and concluded that there were attributes of both formal and informal learning in all of them:

Our analysis strongly suggests that such attributes of formality/informality are present in all learning situations but that the inter-relationships...vary from situation to situation. It is important not to see informal and formal attributes as somehow separate, waiting to be integrated. This is the dominant view in the literature and it is mistaken. Thus, the challenge...is to recognise and identify them and understand the implications. (p. 315)

Instead, these authors characterise "process", "location and setting”, "purposes” and "content” as the dominant distinguishing features about learning that should be considered. The position taken by Malcolm et al. (2003) echoes the NARST Policy Statement quoted earlier (Dierking, et al., 2003). These analyses emphasise the same elements of learning that have been identified as needed for the formal sector. The importance of relevance, of familiar local contexts, of personal choice, together with an understanding of process and purpose, are clearly articulated.

To understand the learning opportunities offered by the informal sector, however, some further synthesis is required. Based on Rennie’s (2007) analysis, we view the contexts for learning in the informal sector as those out-of-school learning environments where (a) both attendance and involvement are voluntary or freechoice, rather than compulsory or coercive; (b) the curriculum, if any, and whether intended or not, has an underlying structure which is open, offers choices to learners and tends not to be transmissive; (c) the activities in which learners can be involved are non-evaluative and non-competitive, rather than assessed and graded; and (d) the social interaction is amongst groups likely to be heterogeneous with regard to age, rather than constrained between same-age peers and formalized with the teacher as the main adult. In sum, compared to formal school environments, learning in the informal sector "is learner-led and intrinsically motivated, rather than teacher-led and extrinsically motivated” (Rennie, 2007, p. 127). 


\section{How is science presented in the informal sector?}

From the perspective of formal education, science learning in the informal sector often appears haphazard and incoherent. Nevertheless, because it is internally rather than externally driven, this kind of learning is often long lasting. It enables constructive building upon existing knowledge to take place. It offers "potentially a more holistic approach to science education, one that better integrates school, work and leisure time learning experiences...[and] could be a more robust approach to long term gains” (Falk, Storksdieck, \& Dierking, 2007, p. 456).

The ways in which science presents itself informally to a broad public are rich and varied. There are museums and environmental centres, clearly focused on portraying aspects of science. There are science-based media which include popular books, television documentaries, and the internet. More subtly, science is presented in advertisements, newspapers and television news, popular films and magazines. Science circuses and other modes of outreach, such as science festivals, attract a wide section of the public. Without doubt, the science is there to find, if the seekers know how to find it and can understand it when they do. The problem with many of these opportunities for learning is that personalised learning outcomes are very difficult to measure, so we have little idea how often, or in what way, they are accessed. Also included in the informal sector, however, and highly relevant to this discussion, are the formally constructed after-school and out-of-school experiences that may be related to the science curriculum. Some of these have been evaluated and yield interesting outcomes (see, for example, Bouillion and Gomez, 2001; Donahue, Lewis, Price and Schmidt, 1998; Gibson and Chase, 2002; Laursen, Liston, Thiry and Graf, 2007). 
In the next sub-sections, we describe some key elements of these different opportunities for learning and synthesise what we know about the effectiveness of their learning outcomes. We acknowledge that these outcomes are not necessarily those required by science curricula and that they are often unstructured. It is the methods of, and the insights from, these informal initiatives that we believe to be relevant to formal schooling.

To make this task manageable, we have clustered the range of environments in the informal sector into just three categories, as described by Rennie (2007). These are: museums and similar institutions which have an educational purpose; community organisations, which are designed/aimed at educating the public about matters usually relating to health and environment, and including after school programmes; and the media, which include print and electronic forms. Each of these areas offers opportunities for learning science outside school and, since we are focused on young people in the early years of high school, we shall review these areas with particular attention to what they offer to students at this level.

\section{What contributions do museums and other institutions make?}

Learning outcomes from museums and like environments have been increasingly well documented over the past thirty years. Research about, and understanding of, learning in these places has been enhanced by taking a broader perspective of the nature of learning. For example, in her discussion of learning science outside of school, Rennie (2007) debunked three major myths about learning in museums. These myths are that: playing and learning cannot occur at the same time; if learning occurs, it must happen at the museum; and what people learn is predictable and therefore easily measurable. Disposing of these myths and recognizing that learning is a personal, contextualised process that takes time, enable us to recognize that having fun, even lots of it, does 
not preclude learning. Learning does not have to be demonstrated at the time of a potential learning event, it may become evident in other situations at a later time. The learning that occurs can be unexpected, unintended, and hence is not captured by traditional “tests". This broader view of learning greatly increases understanding of the potential of museums, and other out-of-school experiences in the informal sector, to contribute to learning science and a range of other cognitive, social and affective outcomes.

What then, about the museum experience, offers insights into why people choose to go there, why after-school activities in museums are popular with students, and why people believe that the experience offers learning opportunities for their children? Bell, Lewenstein, Shouse and Feder (2009) characterised museums, zoos and similar establishments as “designed settings”. They differentiated how learning occurs in such settings from formal learning in several critical ways. First, learning tends to be fluid and sporadic. Second, the settings are experienced episodically. Third, visitors may navigate freely, choosing the exhibits with which they wish to interact. Interaction is facilitated not by a teacher but by

objects, labels, spaces, recorded messages, brief interpretive guides, and occasionally docents or interpreters to facilitate learner engagement. They are designed to serve a diverse public in the myriad social configurations they assemble. Thus, individuals, families, and teen peer groups are all understood as participants whose needs and interests should be accommodated in designed spaces. (p. 127-128)

Thus visitors are essentially in control of their learning and can take what they need from the experience in a unique way. The personal, sociocultural and physical contexts, described by Falk and Dierking (2000) as essential components in understanding the museum experience, also affect learning outcomes in a designed setting and will determine choices to a marked degree.

According to many reports, the public values both the opportunities for learning and the entertainment aspects of a museum or a zoo. Enjoyment is a key 
factor in the decision to visit such an establishment. In a science centre, the challenges presented by interactive exhibits and heightened elements of exploration, curiosity and surprise are also well documented as facilitating engagement (see, for example, Perry, 1989; Sadler, 2006). Semper (1990) felt that the element of curiosity had been underrated, a conclusion borne out by subsequent research. Visitors have reported continuing enthusiasm and interest after the visit (Stocklmayer \& Gilbert, 2002a) and that they gained knowledge, skills and new perspectives (Falk, Scott, Dierking, Rennie, \& Jones, 2004). The list of affective elements of successful interaction is therefore long and ubiquitous.

Bell et al. (2009) listed excitement, delight, awe, and surprise amongst many signs of visitor pleasure at the interactive experience. Understanding the elements that enable such outcomes is important and these were recently identified by a group of exhibit designers as "comfortable - opening the door to other positive experiences; engaging; reinforcing; and meaningful - providing personally relevant experiences that change visitors cognitively and affectively” (Serrell, 2006, as cited in Bell et al., 2009, p. 134). McLean (1993, p. 93) characterised interactive exhibits as providing opportunities to "gather evidence, select options, form conclusions, test skills, provide input and actually alter a situation based on that input”. Rennie and McClafferty (1996) also identified the opportunity for investigation as important for effective learning by younger school students in a science centre, as is confidence building (Perry, 1989).

In zoos and natural history museums, a critical element of interest and engagement is that of narrative. Research by Tunnicliffe and colleagues (Tunnicliffe, 1996; Tunnicliffe, Lucas, \& Osborne, 1997) found that visitors to the museum constructed their own narrative about the specimens, whilst at the zoo the narration 
was about animal behaviour. In Yellowstone National Park, Brody, Tomkiewicz and Graves (2002) found that visitors constructed new knowledge and values relating to the hot springs from four sources: prior conceptions, experience with the environment, discussion amongst fellow visitors and use of the visit brochure. In many zoos and aquaria, opportunities for direct interaction further contribute to the visitor experience with touch-pools (in which visitors, especially children, actually touch small marine flora and fauna), feeding programmes and other ways to facilitate engagement.

There are many research investigations into the outcomes of exhibit interaction from an educational perspective. The science content learned through interactivity, the nature and outcomes of specific exhibit use, promotion of reflections about the nature of science, quality of visitor questions and explanations, understanding science as process, the special context of family visits and the way in which the nature of science is promoted have all been the subject of research studies. Our aim in this paper is not to review all the educational outcomes of various aspects of exhibit interaction. Suffice to say that there is strong evidence for learning, both cognitive and affective, and that the learning is enjoyable. Bell et al. (2009) made the following statements about learning from these environments:

There is evidence of learner excitement and strong positive emotional responses ...There is also clear evidence for learning science content...participants can reflect on the enterprise of science and on their own thinking about science...there is evidence of learners' attempts to personalize and integrate science learning experiences with their values and identity. (p. 161-162)

We point out that the image of science presented in designed settings has also been criticised as often being more about principles than processes, and often implying that science is a closed body of knowledge (for example, Bradburne, 2000; Champagne, 1975; Rennie \& Williams, 2002, 2006). Exhibition presentation modes and themes are slowly changing, however. Arnold (1996) described attempts, such as 
actors dramatising the work of scientists, to enhance the social and cultural aspects of science, and Pedretti (2004) concluded that exhibitions that foregrounded social issues can enhance learning about NOS and how science is socio-culturally situated.

Other "brief encounters" occur within schools when science centres take their programmes on the road. The outreach activities of Questacon, Australia's National Science and Technology Centre, are one example of successful outreach where success is measured in terms of enhanced positive attitudes on the part of both teachers and students. Evaluations of such short visits have indicated the possibility of improved interest and understanding (Burns, O’Connor, \& Stocklmayer, 2003). The key to such improvement is engagement, with its overtones of enjoyment and relevance. Questacon’s programmes encompass all ages, from pre-schoolers in local libraries and play centres, to primary and high school students, and families.

Community participation is seen as critical.

\section{What contributions do community organizations make?}

There are many after-school, science-related voluntary programmes for students and adults. These include those provided through museum outreach activities, communitybased programmes and programmes run by government organisations. Nicholson, Weiss and Campbell (1994) explained that many of these programmes originated with attempts to compensate for the effects of old-fashioned, teacher-directed school science. For this kind of programme, raising students' school-based performance in science is an important goal. Some, like the Exploratorium’s Mission Science Workshop in San Francisco (Altmann, Tamez, \& Bartels, 2001), are directed towards enriching the experience of children from lower socioeconomic backgrounds. Programmes that take place after school are usually more formally constructed and more organised than visits to a museum or a zoo, and tend to focus on a defined target 
audience. These different origins and underlying motives can cause some tensions with formal schooling but their voluntary nature nevertheless offers insights into how the informal sector is currently providing for science learning in ways that many schools are not. Schwartz and Noam (n.d.) comprehensively surveyed after-school programmes in the United States as a background paper for the Bell et al. (2009) report. They made the point that this outreach forms an important bridge to science for many students, especially those from disadvantaged backgrounds.

For the Exploratorium outreach workshop programme, although there may be improved school grades, this is not a core aim. The focus is on student development more generally: "our observations suggest that it helps cross many of the same types of boundaries that vex educators in more formal settings” (Altmann et al., 2001, p. 266). These boundaries are those of equal opportunity in respect of gender, ethnicity, and language. The workshops are designed to engender respect, facilitate ultimate success, promote empowerment and be a safe place for risk and failure. With a clear goal of inquiry, they foster creativity and imagination. Importantly, the authors believe, the workshops “are not like school” (p. 267). According to Schwartz and Noam (n.d.), "examining together all the major meta-analyses in the field of afterschool reveals a striking finding: all reports include some evidence that populations of students deemed to be 'at-risk' are the same students who benefit most from afterschool programmes” (p. 37).

The theme of boundary or border crossing has become a familiar one in school science (Aikenhead, 2001, 2006) and is a critical element in identifying what is appealing about outreach of this kind. Building on the work of Phelan, Davidson and Cao (1991), who described the different cultural worlds of peers and family and the world of school, Costa (1995) added the world of science and explored how students 
could negotiate, or fail to negotiate, the border crossings between these different cultural worlds. Students' success in science is related to the ease of crossing these borders. Schwartz and Noam (n.d.) pointed out that "this is particularly true when working with low income and minority youth. The perceived disconnection between the classroom and students' worlds outside school can lead students to disengage from school science altogether” (p. 9).

\section{A "third space" between schools and community?}

In a classroom-based study, Moje, Collazo, Carillo, and Marx (2001) made the point that there is a need for a "third space” between the cultural worlds of school and community that requires the deconstruction of such boundaries. They recommended bringing together these “competing discourses” to enhance science learning. Moje and colleagues expanded on this idea in a later paper (Moje, Ciechanowski, Kramer, Ellis, Carrillo, \& Collazo, 2004) in which they critiqued the idea that the worlds of home and classroom are necessarily in opposition (p. 42). Their "third space” brings together privileged content and discourses from other content areas.

\footnotetext{
Building bridges is a necessary part of what makes third space because it helps learners see connections, as well as contradictions, between the ways they know the world and the ways others know the world...Unlike the bridge perspective, however, a third space focused on cultural, social and epistemological change....is one in which everyday resources are integrated with disciplinary learning. (p. 44)
}

A critical element of this integration is a focus on peer activities rather than those providing a spurious relevance to young people. For example, Moje et al. (2004) quoted a student who said that he did not need to conduct a physics experiment to determine why he should wear a bike helmet. These authors advocated much more focus on real interests of students as reflected in current popular cultural trends. “Popular culture served as an important fund for the youths’ school learning - a point not typically acknowledged in the work on funds of knowledge” (p. 63). These 
authors noted that youth "often used vicarious representations drawn from popular culture to frame their understanding of science concepts” (p. 64) rather than use evidence related to phenomena in which they had actually participated. Moje et al. argued that young people's reluctance to share their own funds of knowledge requires "that teachers make clear that many different kinds of knowledge and discourses are welcome in the classroom space” (p. 65).

Cultural differences are important for informal engagement, encompassing boundaries that are both ethnic and socioeconomic. For example, Schwartz and Noam (n.d.) pointed out that an "emphasis on cooperative learning is frequently more culturally attuned to students of Latino, Native American and African-American backgrounds, whose cultures crash with the individualistic, teacher-centred nature of most schooling in the United States” (p. 11). As we have noted earlier, this "teachercentredness" is a worldwide phenomenon in science (and other) education. Basu and Calabrese Barton (2006) argued that "funds of knowledge" are important in integrating the school science experience with young people's out-of-school life. Such knowledge is the "historical and cultural knowledge of a community" (p. 468) or, more particularly, of a family. What is most important about this concept is "the recognition of the ways in which the life experiences of an individual within a family or community yield knowledge that is useful, powerful and transferable” (p. 468). Incorporation of such knowledge into academic instruction is grounded in "strategic knowledge and activities essential for achieving the goals a student has for his/her out-of-school life” (p. 468). These authors found that students sustained interest when science experience connected with their own funds of knowledge. The informal experience must therefore echo students’ individual beliefs and experiences. According to Basu and Calabrese Barton (2006), "when students...could choose and 
engage in activities connected to their visions of the future, how they valued relationships, and their definition of science, they developed a strong, long-term commitment to pursuing science” (p. 487). It is likely that a "third space” (Moje et al., 2001) could provide for this to happen.

What are the tangible outcomes of community programmes?

The evaluation of after-school programmes has, predictably, examined the effects on two kinds of outcomes: school performance and science-related attitudes. First, research into the ability of such programmes to enhance school science performance has shown that they do have positive outcomes. Second, assessments of students' attitudes towards science careers, self-confidence and interest also reveal positive outcomes. Many programmes demonstrate outcomes of both kinds. A typical example is the Miami Science Museum's youth programmes which focus on "providing low income youth with training, mentoring, work experience, academic enrichment and skills in the use of technology, while improving their communication and interpersonal skills and self confidence.” Their website (http://www.miamisci.org) states that "the Museum's approach has been profoundly effective, with college and employment success stories attesting to its positive impact.” Reported school exit grades, when contrasted with State averages, are very impressive for this programme. The important question for our purpose, however, is why students attend these programmes in the first place. What is it about such programmes that attract otherwise indifferent students to commit to regular attendance? If we can gain some insights into this aspect, we can begin to understand how the informal sector is counteracting the apparently negative image of school science. Two significant features seem to be the promise of a tangible outcome and a non-judgmental environment. 
The San Francisco Exploratorium's programmes are situated in the neighbourhood and are essentially free drop-in centres for local youth. The tangible outcome is a real artefact made by the student: "Giving students the responsibility of using real tools and machinery, treating them like adults...allows them the opportunity to rise to the occasion, working maturely together and staying focused and safe” (Altmann et al., 2001, p. 261). Students demonstrated increased interest and excitement about science and enhanced school success. It is clear that the atmosphere in the programme is one of respect and responsibility. Similarly, when talking about a short summer programme, Gibson and Chase (2002) stressed that providing a safe, supportive environment, in which students can have an opinion, discuss science informally and ask questions is an important aspect for success.

There are also examples of interventions which take place in school time but are stimulated and supervised by scientific organisations. Laursen, Liston, Thiry and Graf (2007) described an intervention programme conducted by the University of Colorado at Boulder, in which trained graduate students formed a "Science Squad" to go into schools. Although the interventions were of short duration, teachers reported enhanced interest and engagement from students and "ascribed this engagement to the inquiry style of presentation” (p. 53). The effects were observed with both high and low achievers. Stereotypical beliefs about science and scientists were challenged by the programme and students' views were found to change. Further, scientific skills such as critical thinking improved. Teachers themselves reported increased understanding and new ways to approach classroom topics. Aspects of the programme that enhanced these gains were identified as authentic science experiences, specialist knowledge, an inquiry approach, and a break from routine. Teachers’ active participation in the programme was necessary to achieve these gains. Positive 
outcomes also occurred for the presenters: they gained skills in teaching, communication and management, as well as enhanced confidence. All these aspects assisted in their subsequent career achievement. It was critical, however, that the presenters felt that they had the positive and active support of the teachers concerned.

As with the Exploratorium programme described earlier, completing a real project is often the theme of involvement by practicing scientists. Various authors who have commented on "project-based learning” or "community-based learning” emphasised the critical importance of a meaningful context with tangible outcomes and the connections with the wider community (e.g. Donahue, Lewis, Price, \& Schmidt, 1998; Flanagan \& Draper, 2006; Jenkins, 1999; Rennie, 2006). In these situations, students cooperate with scientists or community members to gather data, generally of a biological nature. Flanagan and Draper (2006) stated that such projects transform “teachers telling” into "students doing”. Real projects have engaged Australian students, for example, in a range of community-based activities linked to their school curriculum, but often spilling into after-school hours. Some are run under the auspices of Landcare, a not-for-profit organisation focused on the environment. Typical of such projects is rehabilitation of a local creek by students at a small school who have

brought their neighbouring creek back to life, and are now enjoying the return of platypus, echidna and kangaroo to the area. They are minimising waste in the school, have built vegetable gardens and are collecting their own water for the gardens. (Landcare Heroes, n.d.)

Donahue et al. (1998) found that an inquiry-based approach built around a real community-based project involving students as scientists and scientists as educators was likely to be successful. Essentially this is a picture of partnerships extending across boundaries not normally crossed in school life; an exploration of the third 
space. Such partnerships require time, effort and commitment from scientists, parents and community members, as well as teachers and students.

Evaluations of such joint initiatives have been positive; for example, Donahue et al. (1998) found that students had enhanced scientific literacy. Rennie and Howitt's (2009) evaluation of a national project in which scientists partnered with teachers found considerable benefits for teachers and scientists as well as the students; benefits which included increased knowledge and considerable enjoyment for all concerned. Bouillion and Gomez (2001) reported increased learning of science concepts and skills, of interest in science and empowerment, and an increased understanding of NOS.

Moje et al. (2001) concluded that "project based pedagogy affords students and teachers opportunities to investigate, talk, read, and write about questions of interest to them” (p. 470). These authors cautioned, however, that in a classroom setting, the demands of such pedagogy must be congruent with students' experience and world views. Their proposed construction of a "third space" is accompanied by caveats about the possible consequences of merging boundaries within the classroom environment itself with the potential to "trample on the private spaces of young people and their families” (p. 492).

In summary, therefore, the elements of success in these initiatives are clearly identifiable, albeit requiring careful implementation. Many emphasise social interaction, confidence-building, real-life relevance and creative purposeful activity within a framework of inquiry-based learning. Respect for the learner is at the core of all programmes. Participants’ own goals are addressed rather than externally imposed agendas. Boundary crossing is a recurring theme. 


\section{What contributions do the media make?}

There are two ways in which the media affect learning. The first is through the everyday immersion in the broad media experience that is difficult to categorise. The second is the explicit use of media, such as newspapers, multimedia and films, in the classroom to support the curriculum. This use of the media has been reported since the 1970s (see, for example, Bransford, Franks, Vye, \& Sherwood, 1989; Dubeck, Bruce, Schmuckler, Moshier, \& Boss, 1990; Efthimiou \& Llewellyn, 2006; Mellor, 2003; Nagata, 1999; Perales-Palacios \& Vilchez-Gonzalez; 2002, Rose, 2003).

Reviews of the published effects of educational and other media may be found in Rennie (2007) and Bell et al. (2009). Both these reports conclude that there is much research still to be done. While the reported effects of school-based initiatives are generally positive, in this article we are focusing upon informal learning that is not integrated into the curriculum in this way. We shall confine our attention, therefore, to media experiences outside school.

Research on the effects of various forms of media on science learning is relatively scarce and often anecdotal. Most articles discussing science media come from the discipline of science journalism and take the form of comparative analysis of science content and related issues rather than an evaluation of effect. Brossard and Shanahan (2006) used public understanding of technical terms in the print media to build a "scientific literacy measurement”, based upon the premise that the media are a major source of scientific knowledge. In general, evaluation of the effects of the media is difficult, but there are some reports that offer hints as to why the media experience is likely to facilitate learning. Kozma (1991) postulated that the highly personal nature of the interaction influences the structure, formation and modification of mental models. Kozma also stated that deeper understanding may be fostered as 
people use prior knowledge to process information, with long-term memories coming into play to supplement the information being presented. In a later paper the author added that,

specifically, to understand the role of media in learning we must ground a theory of media in the cognitive and social processes by which knowledge is constructed, we must define media in ways that are compatible and complementary with these processes. (Kozma, 1994, p. 8)

These processes include the iterative nature of learning in informal contexts (Miller, 1998; Stocklmayer \& Gilbert, 2002b), the importance of meaningful remindings (Stocklmayer \& Gilbert, 2002a) and that learning takes time (Falk \& Dierking, 2000).

Although there is a large number of comparative studies of science content of newspapers, films, advertisements and magazines, these are more casual encounters by users and, at least in the case of advertisements, are driven by the vision of science as a commodity (Barns, 1989). We shall not discuss these influences here, although they are important. Our intent is to try to uncover the contextual elements of popular science that appeal to a wide audience in order to understand how these might be applied to more formal science learning.

\section{What contributions do popular science books make?}

Popular books can be described and categorised but the effects of reading them are not easily evaluated. Science fiction has an important role to play but there is little evaluative research about this genre, although it has been around at least since Mary Shelley’s Frankenstein and has had a solid and loyal following. Like science comics, science fiction has sometimes been used in schools and colleges as a teaching device to engage students and encourage debate (see, for example, Segall, 2007).

There is a more recent publishing phenomenon, however, related to books about science. Their success has fostered an "outpouring of science writing”, as 
described by Turney (2001), that created a publishing boom that began some thirty years ago and continues to the present. Reading a popular science book is a proactive exercise, unlike the more casual encounters with science in newspapers and magazines. The kinds of people who read such books have not been described, although evidence from other media would suggest that they are those with an existing interest in science. It is instructive, nevertheless, to identify what is appealing about these books (albeit mainly to older readers) in order to detect some clues about the appeal of science more generally.

Mellor (2003) attributed the publishing boom in part to increased efforts by scientists to address the public understanding of science. From this perspective, the general changes in expectations about the communication of science over the past twenty years (see, for example, House of Lords Report, 2000) have provided a social context that "sanctions" scientists to undertake this kind of activity. Mellor states that popular books "act as nodal points in an intertextual web of mediations of science and provide a non-controversial site for the normative construction of public science” (p. 510). She also believes that "readers approach such texts with expectations that they will 'learn' something” (p. 510). Mellor identified "three main modes of address: the narratival, the expository and the investigative” (p. 511). All three modes are important for informal learning. We have previously identified narrative, in particular, as a key element in effective science communication (Stocklmayer \& Gilbert, 2002b). According to Turney (2001), "every successful non-fiction writer will tell you that the way to engage the general reader is to tell a story” (p. 47). In a later article (Turney, 2006), he added that:

What makes the recent boom in science writing important is that so many authors have got so good at constructing explanations... the key entities in the popular science exposition become characters in an explanatory narrative. So perhaps it does all come down to story-telling. But if so, it is story-telling of a very particular kind. (p. 819) 
Leane (2007) emphasised the value of cross-disciplinary approaches and classic narrative style in the appeal of popular books about physics. These common characteristics were described also by Meyer (2005) who analysed the main features of the 94 most popular science books at that time. Meyer identified 12 features which are likely to aid publishing success. Of these, seven offer general insights into making science more attractive. They are listed in Table 3 and demonstrate the importance of clear, reader-friendly explanations and logical sequence.

Insert Table 3 about here

Turney (2001) also examined explanations in popular science texts, with a view to drawing parallels with Explaining science in the classroom (Ogborn, Kress, Martins, \& McGillicuddy, 1996). His conclusion was that successful science writing does, indeed, mirror the ideal pattern of classroom explanations described by Ogborn et al. (1996). Ideally, providing meaning-making through explanation involves four elements. First, a good explanation should create differences. The author sets out what the reader ought to know relative to what they already know. The second element is to construct entities. Labelling, describing and defining the phenomena to be studied and the underlying ideas are a necessary part of explanation. Third, explanation requires transforming knowledge using analogy and metaphor in order to make ideas understandable. Fourth, it is important to put meaning into matter. Handling phenomena through demonstrations is a good way to show the applicability of scientific theories and concepts, although this is not feasible in books. The evidence, therefore, is that popular books about science achieve success because they 
incorporate many features described as desirable for the effective teaching and learning of science.

What contributions do radio and television make?

Explicit science programming on radio and television has a particular audience (see, for example, Research Councils UK Report, 2002). In the USA, according to Ucko and Ellenbogen (as cited in Bell et al. 2009), "science-and mathematics-based television and radio programmes reach some 100 million children and adults each year” (p. 251). This category of programme, however, includes television documentaries broadcast on the Discovery and the National Geographic Channels. Programmes explicitly labelled as having science content are less frequently aired. For example, “educational” programmes produced as part of a congressional mandate require only “at least three hours a week” of educational television. Such programmes are frequently watched in school time. "Science radio [for adults] takes the form of weekly 1-2 hour programmes” apart from very short (90 second) clips (Bell et al., 2009, p. 251). In Australia, mainstream science programming is similarly limited and is equally likely to attract an already interested audience.

Children's educational programmes in general have been evaluated in controlled studies by a few researchers, such as Fisch (2004), Fisch, Yotive, Brown, Garner, and Chen (1997), Haefner and Wartella (1987), Mares, Cantor, and Steinbach (1999), and Reiser, Williamson, and Suzuki (1988). Their findings are that social contexts can enhance learning and that educational programmes are more likely to be successful if they are entertaining.

Problematically, broader-based programme evaluation is often conducted inhouse by programme producers and is difficult to access. Bell et al. (2009) reported from a review commissioned for their report that 
Much of this material is fugitive literature....for many of our queries respondents (both producers and researchers) were unsure as to whether their reports were public documents....almost all the reports we obtained were funded by the National Science Foundation. (p. 252)

An extensive evaluation was, however, carried out in the USA of "Bill Nye the Science Guy”, a programme for 8- to 10-year olds (Rockman, et al., 1996). This programme is pitched at students and teachers, with supplementary teachers' guides and other materials to aid learning. Because the viewing during the research project was highly planned and supported in both home and in-school settings, the environment for the evaluation was very contrived. We shall therefore highlight just three of the many findings. First, the programmes were found to enhance understanding, especially higher order thinking skills and critical thinking. Second, the researchers found that the quality of children's explanations increased and, third, that differences based on attributes such as gender or ethnicity, decreased.

The nature of adult learning from television has been investigated even less but there are indications from some studies as to what makes for successful learning. These are just hints, however, because most studies have focused on a single programme and the study sample has generally been recruited specifically from viewers or listeners who were asked to pay attention to that programme. Such sampling is clearly flawed. Further, the follow-ups have been short-term. Typical examples of such studies include an experiment by Chew, Palmer, and Kim (1995) in which subjects viewed a television programme on nutrition: pre- and post-test questionnaires indicated that the viewers had gained knowledge from watching the programme. Unfortunately, these kinds of self-assessed outcomes are not especially helpful to this discussion. An exception to this pattern is a large and detailed study of 129 million American adults who watched science-based newscasts. Miller, Augenbraun, Schulhof, and Kimmel (2006) found a high measure of recall of science 
content. "Within salient areas, knowledge or familiarity appear to encourage the retention and recall of new information. The cumulative effect of this process appears to be substantial” (p. 237). These authors found that information about such matters as health and diet were more easily recalled than, for example, new technologies. Of course this only concerns factual recall, but it reinforces the importance of interest in engagement with science.

To understand how television might influence formal learning, especially NOS, we shall focus on what might be gleaned from an analysis of one of the most popular forms of informal science programmes not explicitly aimed at "science education”. Dingwall and Aldridge (2006) examined the television wildlife documentary, which they positioned as situated between science as education and science as entertainment. Wildlife programmes have an extraordinary outreach, described as over 237 million homes in over 160 countries for the Discovery Animal Planet Channel alone (Dingwall \& Aldridge, 2006, p. 132). The authors categorised two sub-genres of importance: "blue chip” which deal directly with mega-fauna in an apolitical way without an intrusive human presence, and "adventure" features which are much more presenter-led (p. 137). The latter, such as Steve Irwin's The Crocodile Hunter, have enjoyed extraordinary popularity with a wide audience. "Blue-chip” are more authoritative and often are narrated by iconic figures, such as Sir David Attenborough. Nevertheless, according to Dingwall and Aldridge, there are similarities. Both forms often have dramatic “Grand Narratives” and are anthropomorphic in their presentation. These narratives may include life and death, the seasons, the struggle for survival, and the universality of family ties (p. 141).

Blue chip programmes may be considered as a "spectacle” and a significant parallel is drawn with the Victorian lantern slide monologue. Dingwall and Aldridge 
(2006) contrasted this “environment of visual splendor” with the cheerful, lower

status style of the adventure programme. The blue-chip presenters

are commentators, standing outside the action and acting as a vehicle for the story. In the presenter led-format, however, the activities and emotions of the presenter are the story.... The organizing Grand Narrative is the quest for enlightenment with the presenter in the role of medieval knight searching for the Grail while encountering various obstacles and potential guides, allies or opponents along the way. (p. 144)

Parallels with video games are striking in this analysis.

One might imagine that the blue-chip narrative, held in high esteem by scientists and public alike, would prove to be a model for informal learning not only about animal behaviour but about the processes of science.

Counter-intuitively, however, when the presenter becomes the story, rather than the wildlife, space is created for a more open narrative.... Where the Grand Narrative is the presenter's quest, the everyday reality of science as full of contingency, untidiness and unsolved problems can be much more easily accommodated....The audience is shown the scientific thought process at work. (Dingwell \& Aldridge, 2006, pp. 144-146)

In the adventure programmes, there exists the possibility that

the viewer can be brought into the puzzles of science and treated as a co-investigator rather than a spectator. The presenter is working with a team, who are contributing in different ways and occasionally disagree. It is the difference between the lantern slide monologue and the interactive discovery centre. (Dingwell \& Aldridge, 2006, p. 146)

Some parallels with this analysis were identified by Dhingra (2003), when addressing the image of science on television. Although the students in her study perceived dramatic formats to convey uncertainty in science knowledge, documentary formats were much less likely to do so. As Dhingra (2006) pointed out,

The key function of televisions is in telling stories. Its intersection with science as a collection of stories about people, their collaborations, controversies, disputes, and ideas, and with television practitioners as institutions and people with their own constraints and preferences, merit continued attention. (p. 118)

In summary, many of the features that make science books achieve the best seller lists are to be found also in popular science on television. Those programmes that feature science as a human, messy, exploratory endeavour have very wide appeal. 
The contribution made by other media: the internet and video games

Science on the Internet is even less well understood than that in other media, yet this is the fastest growing medium in terms of use. Recent data, shown in Table 4, from comparable samples in the USA about where adults get their science knowledge, indicate a dramatic increase in the use of the web compared to other forms of media, and also a noticeable decrease in the importance of what was learned at school.

Insert Table 4 about here

The proliferation of science-based educational websites, many attached to museums and other scientific institutions, provide students and the wider public with ready access to a host of science content. Often this takes the form of the latest science news, which one must assume is accessed by those with an existing general interest in science. Following the theme of the previous two sub-sections, however, we are interested in popular sites that provide science in a less obvious context, especially those that encourage audience participation (sometimes collectively referred to as Web 2.0). One such site is Youtube. The ability of Youtube to generate interest in scientific videos was graphically illustrated by the immediate and wordwide interest in the CERN rap-dancing song about what was actually happening in the giant hadron collider (“Large Hadron Rap”). By mid- 2009, this had attracted around 5 million hits. At that time there were over 350,000 videos on Youtube listed as "science". The human narrative element in these videos can often be as small as a simple commentary accompanying a quirky demonstration, but the elements of trial, error and eventual triumph are evident in many of these short clips. These are much more about process than content and provide fascinating viewing; however, their 
effects are undocumented. Bell et al. (2009) commented upon the potential of the internet as follows:

There are important features of the web that may support science learning in ways that other media do not. Unlike print media, the web allows users to both receive and send information. Through user-selected and designed interfaces, the web can honor diverse ways of knowing and learning, so that users can interact with content and with one another in ways that they deem valuable.....Furthermore, these characteristics of the web - dialogic structure, user direction and organisation, expansive networking of people and resources, and increasingly user created media - resonate with learning science and informal environments. (p. 261)

These characteristics resonate also with the most informed visions for the communication of science more generally.

Some video and on-line games also present science in a narrative context. Participation in online gaming and virtual worlds is growing, with more than 6 million signing up for Second Life alone and video games now generating more money than films (Bell et al., 2001, p. 262). (“Second Life is a virtual world accessible via the Internet. Its users, called 'Residents', interact with each other each other through 'avatars'. Residents can explore, meet other residents, socialize, participate in individual and group activities, and create and trade virtual property and services with one another, or travel throughout the world. Second Life is for people aged 18 and over, while Teen Second Life is for people aged 13 to 17 (Wikepedia). Although virtual worlds offer an opportunity for science outreach to enter a completely different genre, the problems experienced in the real world are likely to be just as difficult in a new format. There is no compulsion for a virtual world participant to choose a science-based encounter, any more than in their real earthly neighbourhood. Games, however, offer the same kinds of opportunities as television - that is, they can present science in a subtly accessible format. An example is Whyville.net, an online community with more than one million users (Feldon \& Gilmore, as cited in Bell et al., 2009, p. 263). On a yearly basis, this community is infected with "Whypox", 
requiring users to take appropriate measures to avoid infection. The result is intensive discussion about disease transfer, but "the overall experience did not significantly increase knowledge of the biological processes underlying infectious diseases” (p. 263).

Nevertheless, we are able once more to identify some elements that indicate why this site is popular. Over 1,000 people participated in the problem of the outbreak of Whypox, sharing resources and discussions. The elements of active involvement, uncertainty of outcomes, life and death, and a strong community narrative were important to the engagement. Whyville.net was not, however, created to be a science learning site, unlike many other educational ones whose success may be more problematic. Aitken (2004), in a comprehensive dissertation about the potential of digital games to communicate science, sounded a note of caution about overtly linking games to formal learning outcomes in science. When designing such a game, he argued,

An easy mistake to make....would be to inadvertently design an educational game ...[if] users of educational media do so at the behest of another (a parent or educator), the central challenge of the educational game designer is to create a game that parents and educators believe will be educational, and this ultimately means sacrificing entertainment if it comes into contact with realism. (pp. 266-267)

Once again, there is conflict between the demands of formal education and free choice, self-directed discovery. There is, however, no doubt that self-directed, iterative learning across various media can be powerful. Bell et al. (2009) concluded that:

Exploring the repeated interaction of multiple media and venues would provide insights into how best to position virtual and physical resources for science learning, including better understanding of the relationship between designed spaces, web sites, book, magazines and digital entertainment. (p. 277)

\section{The factors that foster engagement in the informal sector}


Despite their variety, the different contributors to the informal sector discussed in this section have common themes and they are presented in Table 5. Here, presented in four clusters, are the factors that are mentioned consistently in evaluations of successful initiatives. The first cluster refers to affective factors, often given short shrift in curricular decisions, and the other three reflect the tripartite ideals of science education proposed by Hodson (1998): learning science, learning about science, and doing science.

Insert Table 5 about here

\section{The scope of the contribution of the informal sector}

However critical we are of formal school systems, these institutions will persist. They have been shown, time and time again, to be resistant to large-scale reform. A radical reconfiguration of the traditional model of schooling therefore seems unlikely, in the short term at least. There are constraints on the education that can be provided by the formal sector and Schwarz and Stolow (2006) have described these in the following terms.

a) Limits of time. Traditional schools serve students for only about one thousand hours a year (180 days, 6 hours a day) - not enough time to build both basic reading and math skills and higher level twenty-first century skills.

b) Limits of structure. School buildings and most classrooms have a set physical size. Traditional classrooms - with one teacher and twenty-five to thirty students, each at desks - discourage the type of small group activities and off-site projects that are ideal for building twenty-first century skills.

c) Limits of inertia and bureaucracy. As the past twenty years have amply demonstrated, schools and school districts are entrenched organisms that are resistant to change.

d) Limits of priorities. While many great teachers and a handful of great schools have been able to embed high level skill development into projects, most have chosen to devote more time to basic math and basic reading and have not made time to also focus on a twenty-first century skills agenda. (p. 85) 
It is entirely possible that these constraints may be progressively relaxed in the future. Time at school could be greatly expanded (already the case in some Asian countries such as Singapore), school design may radically change, the governance of schools may become more local (which already applies in several countries including the USA and Australia), the quality and education of teachers could be radically improved (although ever-more career opportunities exist for able people and the competition for state funding will always be fierce). Change is happening, but very slowly and unevenly. Meanwhile, science itself races ahead and the need for all people to have a high-quality science education becomes ever-more pressing.

The informal educational sector, because of its diversity, is relatively immune to bureaucratic control and hence to ossification. It is relatively free to assist in the provision of worthwhile education by means of which young people become actively engaged in learning about science. The scope of the informal sector must be exploited and its limitations overcome. It can provide a third space: a place within which the very different and competing discourses of the school system and the everyday world are reconciled.

This third space, which provides an intermediary space between the formal school system and the everyday world, might be likened to a place somewhere between Roberts' (2007) Vision I, the traditional, inward-looking vision of science curriculum, and Vision II, the more outward looking vision where a curriculum might provide situations that students are likely to encounter as citizens. It would, however, lie closer to Vision II in its emphasis on meaning making and useful knowledge, whilst preserving the values of Vision I in regard to firm theoretical foundations. From another perspective, Venville, Wallace, Rennie and Malone (2002) explored the notion of an integrated curriculum. They suggested that a mix of disciplinary and 
holistic-based science reflected a "worldly perspective" of science curriculum, and "a holistic view of knowledge. This perspective represents pupils’ knowledge as grounded in their experiences, relationships and contexts” (p. 70). Such a view includes disciplinary knowledge as a component, of course, but the contextual component blurs the disciplinary boundaries.

To bridge these often competing, but potentially facilitating, discourses, the informal sector has the capacity to provide for the factors relating to engagement outlined in Table 5. In the following sub-sections, we take these factors and explore how the informal sector might meaningfully and practically contribute to the formal sector. In doing so we acknowledge that many teachers, in many schools, currently make use of the ideas we are presenting. Our concern is that those teachers and those schools are presently too few to have the wide spread effect that we hope to achieve. We are, in essence, arguing for a complementarity between the formal and the informal sectors which would go a considerable way towards meeting the goals of Vision II curricula.

\section{Facilitating the factors leading to greater engagement}

Affective factors

The idea of there being a formal science curriculum in some form will always be used in schools. Within informal provision, however, the curriculum there can be based on a range of declared structures within which learners have a significant yet managed choice. Diversity, together with continuous access to informal provision, will ensure that ideas are available to students when and where they have a need to learn. Such an approach eliminates the unsatisfactory aspect of catering to "the middle of the road" and allows all students to select ideas and material at an appropriate level while remaining within broad school structures. It allows also for the diversity of teacher 
experience, providing scaffolding and extra help where needed. There are already some curricula that have attributes of choice, most notably in project work that we discuss below. While schools find elements of free choice both time-consuming and difficult to administer, the involvement of the informal sector could make it much easier to attain this goal. Greater engagement by students could be achieved.

There is little doubt that passion and interest in science are powerful drivers for learning. There is also evidence, especially from sustained programmes but also from some short interventions, that informal experiences can radically influence a student's interest in science. Challenging experiences do not mean competitive ones, but those which stretch the student's understanding and develop scientific skills. Skill development and elements of personal challenge may be found in many interactive exhibits and in television programmes, including gaming. The knowledge exists in the informal sector of how to utilize these aspects to greatest advantage. There is much more scope for attempts to identify students' interests and to address them effectively.

Undoubtedly, good teachers have always worked to address these affective aspects in their science classrooms. However, it is becoming more difficult to do so as resources in schools dwindle and more safety restrictions are placed on experimentation and external, off-site excursions. The ability of the informal sector to demonstrate, through grand-scale science, the wonders of astronomy, of animal behaviour, or of spectacular chemistry, should not be underestimated. The "Grand Narrative” referred to earlier is in part about wonder and awe and has been demonstrated as intrinsically engaging, with wide appeal. Wonder and awe are, clearly, also related quite closely to the following three aspects: entertainment, interest and enjoyment. 
Konrad Bloch (Nobel Prize winner in 1964) said in his acceptance speech, "I have been happy to have chosen science as my career, and, to borrow a phrase of Jacques Barzun, have felt that 'Science is, in the best and strictest sense, glorious entertainment'”. We must provide for entertainment and enjoyment in the science that our students learn if we are to justify them learning about it. Science in the informal sector relies on entertainment and enjoyment to engage their various publics and to sustain that engagement. It does not mean "dumbing down” but, rather, framing the science in an engaging context.

\section{Factors relating to "learning Science”}

Multidisciplinary or integrated science is messy and often outside a teacher's professional expertise, but it is increasingly the model of modern science. Today's science issues are tackled by interdisciplinary teams. The science represented by abstract canonical concepts, of the kind found in many textbooks, tends to lack context and, because the students themselves have to provide the synthesis that makes it meaningful, it becomes unnecessarily difficult conceptually. The informal sector, less wedded to traditional texts and much more engaged in context-based science, whether in science research institutions, science museums, zoos or in the media, can and does provide for disciplinary integration and a more holistic picture of what science is really like in the world outside of school.

There is evidence that the learning that occurs outside of school is also that which people see as relevant and useful. In part, this is because of the free choice element and voluntary engagement, and also in part because the factor of relevance is well understood by informal providers. Knowledge that comes from the informal sector can more readily be authentic, in that it reflects the processes and current conclusions of science. In this respect, the informal sector has the great advantage of 
being able to offer a much quicker response to new discoveries than is possible in the formal system. It is important to reflect the interests of the group for whom the knowledge is intended - the students. This will enhance the likelihood of sustained engagement and, perhaps, an outcome of choosing a career in science.

Science-based narratives are ubiquitous in the informal sector. For example, museums may present themed exhibitions or exhibits with historical stories to tell. A science show is essentially a narrative, and narratives underlie most broadcast media. Zoos and botanic gardens present narratives concerning the preservation of species and the environment or the lives of animals and plants. A science researcher has a strong narrative framework around which the purpose and outcomes of the research are based. In all these cases, the degree of engagement with the narrative depends upon a person's own relationship with the content and the way in which it is presented. Within the narrative, complex concepts may be embedded and explored.

\section{Factors related to "learning about science"}

Evidence from science centre research and from after-school programmes emphasizes the importance of community in voluntary engagement with science. The informal sector is particularly accessible for border crossing. Learning about science can take place in groups that are socially convenient to the learners and supportive of their interactions, in ways that promote multigenerational learning. This community context sets science in the real world of the student, enabling a better appreciation of complex scientific and social relationships. Further, dealing in schools with science issues of importance to the community facilitates the involvement of students' families and friends. The informal sector provides milieux where this can happen. Interactions with practising scientists offer opportunities for understanding the real ways in which science is conducted, as opposed to the artificial nature of science 
as presented in the text book. The elements of excitement, discovery and satisfaction are important to this process.

\section{Factors related to "doing science”}

How can students understand NOS if they never encounter it? It has been said that the science we do is not the science we teach, and this unpalatable truth is often quite clear to students. Classroom science is often contrived and unreal, but classroom science cannot hope to replicate real processes, whereas scientists themselves can contribute much to explain science as it is practised. Real projects with meaningful outcomes have been shown to engage students, especially when real scientists are involved. If scientists and other experts are to be involved, however, it can be neither ad hoc nor sporadic. Positive partnerships require commitment from scientists and their employing organisations. They also require considerable time for planning with teachers to integrate projects into the curriculum that provide opportunities for choice and for students to play different roles best suited to their interests. Scientists may have to be educated about successful communication with students of different ages and understandings.

\section{How can the informal sector make its full contribution?}

Models for the relationship

Three models for the relationship between the formal and informal sectors can be identified:

a) The formal and informal sectors are unrelated. The formal sector continues to see itself as the sole custodian of science education and continues to change at a rate defined by its governmental parameters and resources available. The informal sector sees itself as providing entertainment, using science as a vehicle, and changes at a rate determined by the commercial imperative, i.e. to get people to make use of it. 
b) The formal sector remains the main custodian of science education, but makes explicit use of the special capabilities of the informal sector, e.g. access to up-todate science, opportunities for self-directed enquiries.

c) The formal sector integrates the capabilities of the informal sector into its everyday working, thus creating a "third space" for science education.

These models are idealised for, as we have seen, many manifestations of the two sectors share common purposes, content, and pedagogies. Nevertheless, an explicit espousal of either model (b) or, better still (c), as we have argued above, would enable some of the current challenges to the formal sector to be successfully and speedily met. But doing so will in itself present new challenges.

\section{Taking the informal sector into the formal sector}

If the informal sector is to contribute in one of more of these ways, how can it happen? First, we contend that it is unproductive to expect schools to provide more opportunities for visiting out-of-school sites. Current administrative structures, particularly school timetabling, make it difficult to take students out for a day, or even half a day, although these problems may be partially overcome with careful planning and less public concern about "health and safety". A second, more serious issue militating against school excursions is that of liability. This is discouraging school excursions in many countries and the current constraints are likely to get worse. Last, there are matters of increasing expense related to taking students out of school. We should focus, therefore, on the "third space" as a place in which students can encounter the offerings of the informal sector within the school.

New technologies are encouraging in this regard. In Australia, Questacon, the National Science and Technology Centre, is experimenting with real-time broadband video interaction into a series of linked classrooms, delivering lively science presentations and discussions that have the extra advantage of allowing students to talk to those in other schools as well as the presenters synchronously. Although in its 
infancy, this form of interactive television is exciting and engaging and students are reacting positively. The internet and mobile technologies also offer new ways to reach students and new ways of presenting science. Scanlon, Jones and Waycott (2005) reported encouraging outcomes for the use of mobile technologies, particularly with adults in informal learning settings but also with tertiary and secondary students. "One key finding was that students each had access to their own learning materials on the handheld computer, and so maintained a sense of personal ownership over the data and project" (p. 7). Scanlon et al. also noted that "mobility and portability provide a communication channel between the technological wireless network and the social, face-to-face network, and mediate the social interaction of the participants” (p. 14). Some science teachers are using Youtube for short science videos and lesson information for students to access outside of school hours. In Australia, however, access to the Internet in schools is somewhat restricted for ethical reasons, which is frustrating, so new ways must be found to make the most of these technologies. It is likely that simultaneous access from various classrooms into programmed and timetabled interaction might be one solution.

The third space, however, is not simply the undefined ethereal space of the world-wide web. It is the potential real space into which the informal sector can move, bridging the gap between school and community and hence blurring the boundaries between them. This space is presently quite empty, occupied here and there by an enthusiastic scientist, an outreach programme from a science centre or a university, or an enthusiastic after-school provider. We believe that the potential for use of this space is much greater than this sporadic and incoherent activity. To exploit it will require resources and careful planning and synthesis, plus a deal of goodwill from informal providers and from cooperating schools. Critically, it requires 
acknowledgement from the world of formal education (and from the wider public and policy-makers) that help is needed, that all cannot be solved from within the system, and that yet another new curriculum will not solve the problems of science education. It also requires reform within the informal sector. Many museums, zoos and science centres have educational outreach arms that understand and respond to local curricula. So, too, do television and other media. Universities, increasingly, are focusing on outreach and recognise the importance of schools to their own survival. In all cases, however, science content will need scrutiny and some providers will require training in how to engage students.

How might the creation of a third space be viewed by educational stakeholders?

We earlier identified as a central issue: how can school science education both prepare some students to go on to careers in science and technology and prepare all students to be responsible, scientifically literate, citizens? The relationship between the world of science and the public has undergone profound changes in the past ten years, resulting in new assessments of what a scientifically aware public might need to know. For example, Rennie and Stocklmayer (2003) envisioned that public involvement with science and technology might result in

- People who feel that science and technology lie within their interest and their personal lives.

- People who feel that the nation's science is both their property and their responsibility.

- People who are able to access new knowledge in science and technology and understand how it will affect their lives.

- People who feel comfortable about processing relevant scientific information so that their personal areas of interest are well served.

- People who feel that their own knowledge and concerns are valued by the scientific community. (p. 771)

Duggan and Gott (2002) drew attention to the rapid change of science when they stated: “As controversial science-related issues emerge and the uncertain nature 
of science is clearly exposed, the public are being confronted with science in ways that they were not in the past” (p. 662). Duggan and Gott suggested that reforms could proceed more logically if it was clear what kind of science was needed. This could "lead to a content that articulates with today's society and one that prepares young people for the opportunities, responsibilities and experiences of adult life” (p. 663). They concluded that the elements which would be important to such content were that students need to know, understand and be able to apply "concepts of evidence and the overarching concepts of validity and reliability” (p. 674), and that they should know how to access conceptual knowledge which is directly related to topical issues. Such demands were clearly evidenced in a report by Alsop and Watts (1997) on informal learning about radiation hazards by adults in an English village. These authors concluded that models of conceptual change that neglect the affective dimension and the applicability of knowledge are likely to be incomplete. Usefulness is a key factor and, crucially, “any model of conceptual change that disregards learners’ self-esteem and self-perception is defective” (pp. 647-648).

It is likely that any moves to integrate informal learning more closely with formal education will meet with general approval. In the UK, at least, a recent government document gives a strong indication of a public view that echoes many of the sentiments in this paper. The Department for Business, Innovation and Skills prepared a consultation document, entitled "A Vision for Science and Society” (Department for Business, Innovation, \& Skills, 2008), that assessed a range of public opinions on matters such as public engagement, governance and so on, through methods which included a survey, focus groups, and specific consultation. A synthesis of the total of 3,200 consultation responses, drawn from business, education, the media, policy-makers, scientists and the general public, revealed an unambiguous 
recommendation for more informal involvement in formal education (Department for Business, Innovation, \& Skills, 2009). We mention this survey here principally to make it clear that the problems of school science are recognized by all sections of the community, and further, that there is recognition of the potential of out-of-school sources to assist science learning.

\section{Realising the third space}

In the Science and Society consultation process (Department for Business, Innovation, \& Skills, 2009), many suggestions were made to policy makers about increasing the engagement of schools with parents, scientists and industry. Proposals included scientists visiting schools although, to be effective, it was felt that scientists need training to do this well. There were also many comments about the use of the Internet and other new technologies, with the general feeling being that presently they are under-used for educational purposes.

The summary report (Department for Business, Innovation, \& Skills, 2009) identified the culture of school science as problematic, advocating "the promotion of excitement for science alongside scientific rigour to create a population able to evaluate scientific issues critically” (p. 11). Negative perceptions of school science included an image problem, lack of inspiring role models, and lack of teaching of communications skills and other tools for scientists, all of which have been identified in the literature we have quoted earlier. Sadly - and critically - no positive perceptions about the culture of science in schools were noted in any responses. Negative perceptions about the teaching of science were many and damning. They included lack of professional development and lack of teachers’ pedagogical content knowledge (especially at the primary level). These, too, are not new perceptions, but "a common concern was that teachers, pupils and parents do not feel empowered to 
use locally available or topical resources or develop local partnerships” (p. 13). Such empowerment would sanction teachers' engagement in such partnerships, requiring this third space to be clearly articulated at a policy level and to be energetically pursued by all sectors that have the potential to contribute.

If a third space is to be exploited, then two things need to happen. First, schools need to acknowledge that they will benefit from external involvement. This requires active collaborative planning for a different, inclusive mode of delivery. Second, the elements of the informal sector that might be partners in this delivery need to re-evaluate how they operate. It will not be enough for a scientist to drop in and have a chat about recent research, or for a science centre to rely only on traditional exhibit-based interactions. A holistic approach, driven by the school system itself, is the only practical solution. The role of new technologies will be critical in this regard.

\section{Making a difference: Enhancing what is learned in school}

The overwhelming evidence that students do not remember most of the science they learn in school (recall the low value adults put on school science knowledge, reported in Table 4), together with the wealth of literature on misconceptions, has been largely ignored by the formal sector in framing curricular content. A fresh approach using the expertise and talent of the informal sector offers some prospect of addressing these problems because the science content is more likely to be grounded in, or substantially related to, contexts that are recognisable in the world of today and tomorrow. Science centres, and increasingly zoos and museums, have a wealth of practical, hands-on expertise and ways of presenting science that are engaging and entertaining. Many are currently examining their public spaces to bring more social contexts into the science they present. The media are embracing new technologies, in 
particular web interactions, to enhance their appeal to young people. Research scientists are being encouraged to step out of the laboratory and into the public domain.

Steps in the planning should therefore include identification of relevant themes and ways to address these through the informal sector. This is not difficult: focus groups of adults as well as young people can, at short notice, identify the themes that are of immediate or pending relevance to their lives. Material that falls within the scope of the Vision II curricula described earlier can be clearly identified together with key concepts that are generally agreed to be both important and potentially engaging. The Nature of Science can also be addressed more explicitly.

We have not forgotten the importance of assessment in the formal system. Although we find the current summative approach to assessment stifling, it is quite possible to integrate valid and reliable assessment into more interesting and exciting activities than is currently the case. Indeed, creative assessment methods, embedded in the activity or experience, can be a further tool to inform the learner and thus promote learning. Current reliance on summative assessment processes is destructive to both teaching and learning.

The individual learner forms the focus of all the contributions to the informal learning of science. Essentially learning is carried out at a pace dictated by that individual, providing for different approaches. A great range of forms of provision within the informal sector has been outlined in this paper. This range ensures that both the intellectual demands of the huge diversity of themes in modern science and the learning preferences of young people can be met. If we are to heed the findings of educational research, especially in respect of life-long learning, then we must radically revise our approach to science education to allow for such individual 
progress. The informal sector must reach out and, together with the formal sector, populate the third space in which the needs of the individual must be paramount.

What might a "third space" curriculum module look like?

A few years ago, one of the authors (SS) designed a module for a new syllabus in the Australian state of Tasmania, which required disciplinary integration and grounding in social contexts. These new syllabus requirements placed considerable pressure on teachers to plan and teach in a new way, and many were experiencing great difficulties because individual topics were not specified or described. The only requirement was that teachers choose a science topic to satisfy the particular generalized learning outcomes for that year. These included traditional outcomes for knowledge and skills such as investigating scientifically, understanding fair testing and controlling variables. It also included appreciating the tentative nature of knowledge, the value of history and the importance of creative, imaginative and speculative thinking. The interdependency of systems on local and global scales was stressed, as was design, construction and evaluation of products and processes.

The subject of the module was chosen to be the traditional and ubiquitous topic of buoyancy, designed for a second or third year high school group (13-14 years). We present this outline, somewhat modified to fit within the parameters identified earlier in this paper, not to suggest that it is ideal, but to illustrate some modest possibilities of informal contributions from the media and the Internet, research and industry scientists, and science centres and museums in a classroom setting at the present time and within existing curricula. The broad goals for the module were drawn from traditional physics in a reassuringly recognizable framework closely allied to a Vision I statement: 
Students will investigate the concepts underlying buoyancy. They will gain an understanding of the basic principles which cause objects to float or sink and explore the relationship between shape, nature of materials and the nature of fluids in which materials are immersed.

Within these curricular demands, however, a range of teaching and learning strategies was designed which are consonant with Vision II ideas.

\section{Choice of content}

The "contexts" in this case were twofold: the boat-building industry in Tasmania and the environmental threats to marine fauna and flora around the coast and these drove the choice of content.

Students will consider some of the history of boats, of marine pollution and the importance of these issues to future boat design and to the community.

The Nature of Science was addressed through considerations of actual research methods as described by visiting scientists and designers, and through inclusions of elements of the history of science, of creative and imaginative thinking, the interdisciplinary nature of current scientific issues and the nature of interdependent systems

Teaching and learning methods: Issues in the processes of curriculum design

The module featured ideas drawn from a wide variety of stakeholders, including the students themselves, and was designed to give teachers and students greater flexibility in working with issues of local relevance. The overall lesson plan is presented in the Appendix to this paper, where the involvement of the informal sector is delineated. In terms of student experiences and the attributes of informal learning that we have listed above (see Table 5), this module has elements of the following:

- Some aspects of free choice: Although limited within one topic, students have choice regarding their design projects and their research projects. (This aspect needs much more flexibility to truly provide for student diversity.) 
- Challenging activities: Challenge is present in several of the activities in this module but is overt in the Group Design Competition. There are several activities, especially the demonstration design activity, which require motivation and drive.

- Aspects of the wonder of science: This is particularly emphasised in the research into deep sea creatures, with museum assistance.

- Entertaining presentations: These include science shows, student performances and a highly popular film.

- A holistic approach: The marine issues addressed in this module have aspects of community involvement, economics, environmental issues, principles of physics, biology and chemistry, amongst others.

- Use of prior knowledge and recent research: Students are specifically encouraged to use their own knowledge at several points, including discussions on scuba diving and the deep, interactions with visiting professionals, Internet investigations, and so on.

- Aspects of narrative: The two contexts identified above constitute the major narratives in this module.

- Simple jargon-free science and the use of models: These are particularly emphasised in the science centre presentations.

- Connections to community: Project activities could well involve overt connections to community.

- Science as messy and human: These aspects are evident in the activities.

- Real projects in an inquiry-based environment: The connections with a marine biologist provide for these, but other activities also foster inquiry-based thinking.

The module thus requires the teacher to accommodate student-led learning whilst carefully guiding theoretical directions, assisted by critical elements of skills and resources from the informal sector. Whilst we acknowledge that many teachers already involve these kinds of elements in the classroom from time to time, this module incorporates such elements as a fundamental framework. It is only an outline, however, and it will be open to more exploration and development as informal resources improve - particularly with respect to new technologies.

\section{Concluding comments}

The informal sector has only recently been recognised as an educational provider.

Historically, public expenditure on research and development into the effectiveness of the informal sector in this role has been both very low and organisationally fragmented. This is changing radically in several countries, for example, Korea, 
Taiwan and China, where new integrating and innovatory structures are rapidly taking shape, as seen by one of us (JG). These are focused on developing and implementing major curricula reforms such as the placing of a greater emphasis on 'modern science' and on 'creativity'. If the potential of the informal sector, as outlined above, is to be realised, we have identified a number of issues that require urgent attention.

The outstanding need is for resources to be made available to facilitate communication and collaborative planning between informal providers and schools in an atmosphere of mutual respect. To draw an analogy with science communication frameworks, we must move from ideas of "public understanding of science”, that have been described as top-down, arrogant and disrespectful, to processes of “dialogue”. The dialogue must extend to students, parents and community. In this process, teachers must not be disempowered, but assisted through professional development (which can be facilitated by the informal sector) to be more comfortable with the inevitable sharing that will result. Issues of timetabling and allied problems must be tackled globally, so that the informal provisions for schools can be extended across the formal sector as widely as possible with the minimum of effort. The informal sector must target outreach activities to the requirements of the curriculum and ensure that those involved in providing science outreach are suitably trained and qualified to do so.

Of course all science education cannot be provided in this way. The plans must be strategic, recognizing also the demands and restrictions on different providers and on schools. If the whole enterprise becomes unwieldy, it will not work. New technologies must be used to maximum advantage in this regard. Hands-on science is in its element in this kind of environment. 
The "captains of the ships" of formal science education, (amongst others, those responsible for curricular reform) have been guilty of wasting resources, time and effort - and ignoring research findings - in trying to find new ways to engage students and improve outcomes. All evidence indicates that this effort, however laudable, has generally been far from being as successful as is needed. We suggest that, rather than relying on a single hulled vessel, the metaphor change to that of a catamaran: the twin hulls of the formal and the informal sectors contributing what they do best to move science education forward. 


\section{References}

Aikenhead, G. S. (2001). Students' ease in crossing cultural borders into school science. Science Education, 85, 180-188.

Aikenhead, G. S. (2006). Science education for everyday life. New York: Teachers College Press.

Ainley, J., Kos, J., \& Nicholas, M. (2008). Participation in science, mathematics and technology in Australian education (ACER Research Monograph No 63). Camberwell, Victoria, Australia: Australian Council for Educational Research.

Aitkin, A. L. (2004). Playing at reality. Unpublished PhD thesis. The Australian National University, Canberra, Australia.

Alsop, S., \& Watts, M. (1997). Sources from a Somerset village: A model for informal learning about radiation and radioactivity. Science Education, 81, 633-650.

Altmann, V., Tamez, M., \& Bartels, D. (2001). Learning by building (destroying and tinkering too): A powerful science communication tool. In S. M. Stocklmayer, M. M. Gore, \& C. Bryant, (Eds). Science communication in theory and practice (pp. 257-268). Dordrecht, The Netherlands: Kluwer.

American Association for the Advancement of Science (AAAS). (1989). Project 2061: Science for all Americans. Washington, DC: AAAS.

Arnold, K. (1996). Presenting science as product or as process: Museums and the making of science. In S. M. Pearce (Ed.), Exploring science in museums (pp. 57-78). London: The Althone Press.

Barmby, P., Kind, P. M., \& Jones, K. (2008). Examining changing attitudes in secondary school science. International Journal of Science Education, 30, 1075-1093.

Barns, I. (1989). Interpreting media images of science and technology. Media Information Australia, 54, 22-29.

Basu, S.J., \& Calabrese Barton, A. (2006). Developing a sustained interest in science among urban minority youth. Journal of Research in Science Teaching, 44, 466-489.

Bell, P., Lewenstein, B., Shouse, A. W., \& Feder M. A. (Eds.). (2009). Learning science in informal environments: People, places, and pursuits. Washington, DC: The National Academies Press.

Berliner, D. C. (2009). Our impoverished view of educational reform. Teachers College Record, 111(1), 1-28.

Black, P. (1995). 1987 to 1995-The struggle to formulate a national curriculum for science for England and Wales. Studies in Science Education, 26, 159-188.

Black, P., \& Atkin, J. M. (Eds.). (1996). Changing the subject. London: Routledge.

Bouillion, L. M., \& Gomez, L. M. (2001). Connecting school and community with science learning: Real world problems and school-community partnerships as contextual scaffolds. Journal of Research in Science Teaching, 38, 878-89.

Bradburne, J. M. (2000). Tracing our routes: Museological strategies for the $21^{\text {st }}$ century. In B. Schiele \& E. H. Koster (Eds.), Science centers for this century (pp. 35-85). Québec, Canada: Éditions MultiMondes.

Bransford, J. D., Franks, J. J., Vye, N. J., \& Sherwood, R. D. (1989). New approaches to instruction: Because wisdom can't be told. In S. Vosniadou \& A. Ortony (Eds.), Similarity and analogical reasoning (pp. 470-497). New York: Cambridge University Press. 
Brody, M., Tomkiewicz, W., \& Graves, J. (2002). Park visitors' understanding, values and beliefs related to their experience at Midway Geyser Basin, Yellowstone National Park, USA. International Journal of Science Education, 24, 11191141.

Brossard, D., \& Shanahan, J. (2006). Do they know what they read? Science Communication, 28, 47-63.

Burns, T. W., O'Connor, D. J., \& Stocklmayer, S. M. (2003). Science communication: A contemporary definition. Public Understanding of Science, 12, 183-202

Bybee, R. W. (1985). The restoration of confidence in science and technology education. School Science and Mathematics, 85(2), 95-108.

Bybee, R. W., \& DeBoer, G. (1994). Research on the goals for science education. In D. L. Gabel (Ed.), Handbook of research on teaching and learning of science (pp. 357-387). New York: Macmillan.

Champagne, D. W. (1975). The Ontario Science Center in Toronto: Some impressions and some questions. Educational Technology, 15(8), 36-39.

Chew, F., Palmer, S., \& Kim, S. (1995). Sources of information and knowledge about health and nutrition: Can viewing one television program make a difference? Public Understanding of Science, 4, 17-29.

Costa, V. B. (1995). When science is "another world": Relationships between worlds of family, friends, school and science. Science Education, 79, 313-333.

Crane, V., Nicholson, H., Chen, M., \& Bitgood, S. (Eds.). (1994). Informal science learning: What research says about television, science museums, and community-based projects. Dedham, MA: Research Communications Ltd.

Davis, K. (2003). Change is hard: What science teachers are telling us about reform and teacher learning of innovative practices. Science Education, 87, 3-20.

DeBoer, G.E. (2000). Scientific literacy: Another look at its historical and contemporary meanings and its relationship to science education reform. Journal of Research in Science Teaching, 37, 582-601.

Dekkers, J., \& de Laeter, J. (2001). Enrolment trends in school science in Australia. International Journal of Science Education, 23, 487-500.

Department for Business, Innovation, and Skills. (2008). A vision for science and society. A consultation on developing a new strategy for the UK. Retrieved February 16, 2009 from http://interactive.bis.gov.uk/scienceandsociety/site/download/

Department for Business, Innovation, and Skills. (2009). Science and society: Summary of consultation responses. Retrieved February 16, 2009 from http://interactive.bis.gov.uk/scienceandsociety/site/category/consultation/

Dewey, J. (1902). The child and the curriculum. Chicago: University of Chicago Press.

Dhingra, K. (2003). Thinking about television science: How students understand the nature of science from different program genres. Journal of Research in Science Teaching, 40, 234-256.

Dhingra, K. (2006). Science on television: Storytelling, learning and citizenship. Studies in Science Education, 42, 89-123.

Dierking, L. D., Falk, J. H., Rennie, L., Anderson, D., \& Ellenbogen, K. (2003). Policy statement of the "Informal Science Education" Ad Hoc Committee. Journal of Research in Science Teaching, 40, 108-111.

Dingwall, R., \& Aldridge, M. (2006). Television wildlife programming as a source of popular scientific information: A case study of evolution. Public Understanding of Science, 15, 131-152. 
Donahue, T. P., Lewis, L. B., Price, L. F., \& Schmidt, D. C. (1998). Bringing science to life through community-based watershed education. Journal of Science Education and Technology, 7(1), 15-23.

Donnelly, J. F. (2002). The 'humanist' critique of the place of science in the curriculum in the nineteenth century, and its continuing legacy. History of Education, 31, 535-555.

Dubeck, L.W., Bruce, M.H., Schmuckler, J.S., Moshier, S.E., \& Boss, J.E. (1990). Science fiction aids science teaching. The Physics Teacher, 28, 316-318.

Duggan, S., \& Gott, R. (2002). What sort of science education do we really need? International Journal of Science Education, 24, 661-679.

Durant, J. R., Evans, G. A., \& Thomas, G. P. (1989). The public understanding of science. Nature, 340, 11-14.

Efthimiou, C. J., \& Llewellyn, R. A. (2006). Avatars of Hollywood in physical science. Physics Teacher, 44, 28-32.

Eraut, M. (2004). Informal learning in the workplace. Studies in Continuing Education, 26, 247-273.

European Commission. (2007). Science education now: A renewed pedagogy for the future of Europe. Brussels, Belgium: European Commission, DirectorateGeneral for Research.

Falk, J. H. (2009, April). Public understanding of science: Where and why people learn science. Paper presented at the Annual international Conference of the National Association for Research in Science Teaching, Garden Grove, CA.

Falk, J. H., \& Dierking, L. D. (2000). Learning from museums: Visitor experiences and the making of meaning. Walnut Creek, CA: Altamira Press.

Falk, J. H., Scott, C., Dierking, L., Rennie, L., \& Jones, M. C. (2004). Interactives and visitor learning. Curator, 47, 171-198.

Falk, J. H., Storksdieck, M., \& Dierking, L. D. (2007). Investigating public science interest and understanding: evidence for the importance of free-choice learning. Public Understanding of Science, 16, 455-469.

Fensham, P. J. (1985). Science for all: A reflective essay. Journal of Curriculum Studies, 17, 415-435.

Fensham, P. J. (1992). Science and technology. In P. W. Jackson (Ed.), Handbook of research on curriculum (pp. 789-829). New York: Macmillan.

Fensham, P. J. (1998). The politics and legitimating and marginalising companion meanings: Three Australian case studies. In D. A. Roberts \& L. Ostman (Eds.), Problems of meaning in science curriculum (pp. 178-192). New York: Teachers College Press.

Fensham, P. J. (2008). Science education policy-making: Eleven emerging issues. UNESCO. Retrieved October 10, 2008, from http://unesdoc.unesco.org/images/0015/001567/156700e.pdf.

Fisch, S.M. (2004). Children's learning from educational television. Mahwah, N.J.: Lawrence Erlbaum Associates.

Fisch, S. M., Yotive, W., Brown, S. K. M., Garner, M. S., \& Chen, L. (1997). Science on Saturday morning: Children's perceptions of science in educational and non-educational cartoons. Journal of Educational Media, 23, 157-167.

Flanagan, R. \& Draper, K. (2006). Education and the environment: Partners for change. Retrieved February 15, 2009, from

http://eetap.org/media/pdf/PartnersFINAL 45 06.pdf 
Gibson, H., \& Chase, C. (2002). Longitudinal impact of an inquiry-based science program on middle school students' attitudes toward science. Science Education, 86, 693-705.

Gilbert, J. K. (2006). On the nature of context in chemical education. International Journal of Science Education, 28(9), 957-976.

Gilbert, J. K., Osborne, R. J., \& Fensham, P. J. (1982). Children's science and its consequences for teaching. Science Education, 66(4), 623-633.

Goodrum, D., Hackling, M., \& Rennie, L. (2001). The status and quality of teaching and learning of science in Australian schools: A research report. Canberra, Australia: Department of Education, Training and Youth Affairs.

Haefner, M.J., \& Wartella, E.A. (1987). Effects of sibling co-viewing on children's interpretations of television viewing. Journal of Broadcasting and Electronic Media, 31, 153-168.

Harris, K-L, Jensz, F., \& Baldwin, G. (2005). Who's teaching science: Meeting the demand for qualified science teachers in Australian secondary schools (Report prepared for the Australian Council of Deans of Science). Melbourne, Australia: Australian Council of Deans of Science.

Hodson, D. (1990). A critical look at practical work in school science. School Science Review, 71(256), 33-40.

Hodson, D. (1998). Science fiction: The continuing misrepresentation of science in the school curriculum. Curriculum Studies, 6 (2), 191-216.

House of Lords. (2000). Report of the Select Committee on Science and Society. London: House of Lords.

Jenkins, E. W. (1999) School science, citizenship and the public understanding of science. International Journal of Science Education, 21, 703-710.

Jenkins, E. W., \& Pell, R. G. (2006). The Relevance of Science Education Project (ROSE) in England: A summary of findings. Leeds, UK: Centre for Studies in Science and Mathematics Education, University of Leeds.

Kahle, J. B. (2007). Systemic reform: Research, vision, and politics. In S. Abell \& N. G. Lederman (Eds.), Handbook of research on science education (pp. 911942). Mahwah, NJ: Lawrence Erlbaum Associates.

Kozma, R. (1991). Learning with media. Review of Educational Research, 61(2), 179212.

Kozma, R. B. (1994). Will media influence learning? Reframing the debate. Educational Technology Research and Development, 42, 7-19.

Landcare Heroes (n.d.) retrieved July 2, 2009 from http://www.landcareheroes.com/profile/wyong-creek-public-school/2/14/

Laugksch, R. C. (2000). Scientific literacy: A conceptual overview. Science Education, 84(1), 71-94.

Laursen, S., Liston, C., Thiry, H., \& Graf, J. (2007). What good is a scientist in the classroom? Participant outcomes and program design features for a shortduration science outreach intervention in K-12 classrooms. CBE-Life Sciences Education, 6, 49-64.

Leane, E. (2007). Reading popular physics. Aldershot, UK: Ashgate.

Lederman, N. G. (2007). Nature of science: Past, present, future. In S. Abell \& N. G. Lederman (Eds.), Handbook of research on science education (pp. 831-880). Mahwah, NJ: Erlbaum.

McLean, K. (1993). Planning for people in museum exhibitions. Washington, DC: Association of Science-Technology Centers. 
Malcolm, J., Hodkinson, P., \& Colley, H. (2003). The interrelationships between informal and formal learning. Journal of Workplace Learning, 15, 313-318.

Mares, M., Cantor, J., \& Steinbach, J. B. (1999). Using television to foster children's interest in science. Science Communication, 20, 283-297.

Martin, L. M. W. (2004) An emerging research framework for studying informal learning and schools. Science Education, 88(S1), pp. S71-S82.

Mellor, F. (2003). Between fact and fiction: Demarcating science from non-science in popular physics books. Social Studies of Science, 33, 509-538.

Meyer, A. (2005). The fairy tales of science. Unpublished PhD thesis. The Australian National University, Canberra, Australia.

Millar, R. (1996). Designing a curriculum for public understanding of science. Education in Science, 166, 8-10.

Millar, R., \& Osborne, J. (Eds.). (1998). Beyond 2000: Science education for the future (The report of a seminar series funded by the Nuffield Foundation). London: King's College London, School of Education.

Miller, J. D. (1998). The measurement of civic scientific literacy. Public Understanding of Science, 7, 203-223.

Miller, J. D., Augenbraun, E., Schulhof, J., \& Kimmel, L.G. (2006). Adult learning from local television newscasts. Science Communication, 28, 216-242.

Moje, E. B., Ciechanowski, K. M., Kramer, K., Ellis, L., Carrillo R., \& Collazo, T. (2004). Working toward third space in content area literacy: An examination of everyday funds of knowledge and discourse. Reading Research Quarterly, 39, 38-70.

Moje, E. B., Collazo, T., Carillo, R., \& Marx, R.W. (2001). "Maestro, what is quality?” Language, literacy and discourse in project-based science. Journal of Research in Science Teaching, 38, 469-495.

Nagata, R. (1999). Learning biochemistry through Manga: Helping students learn and remember, and making lectures more exciting. Biochemical Education, 27, 200-203.

National Research Council. (1996). National science education standards. Washington, DC: National Academies Press.

Nicholson, H. J., Weiss, F., \& Campbell, P. B. (1994). Evaluation in informal science education: Community-based programs. In V. Crane, H. Nicholson, M. Chen, \& S. Bitgood (Eds.), Informal science learning: What research says about television, science museums, and community-based projects (pp. 15-59). Dedham, MA: Research Communications Ltd.

OECD Global Science Forum. (2006). Evolution of student interest in science and technology studies: Policy report. Retrieved September 3, 2006, from http://www.oecd.org/dataoecd/16/30/36645825.pdf.

Ogborn, J., Kress, G., Martins, I., McGillicuddy, K. (1996). Explaining science in the classroom. Buckingham, UK: Open University Press.

Osborne, J., \& Collins, S. (2000). Pupils' views of the role and value of the science curriculum: A focus group study. International Journal of Science Education, 23, 441-468.

Osborne, J., Duschl, R., \& Fairbrother, R. (2002). Breaking the mould? Teaching science for public understanding. (A report commissioned by the Nuffield Foundation. London: The Nuffield Foundation.) Retrieved January 22, 2009, from www.kcl.ac.uk.

Paechter, C. (1998). Schooling and the ownership of knowledge. Curriculum Studies, 6 (2), 161-176. 
Perales-Palacios, F. J., \& Vilchez-Gonzalez, J. M. (2002). Teaching physics by means of cartoons: A qualitative study in secondary education. Physics Education, 37, 400-406.

Pedretti, E. (2004). Perspectives on learning through critical issued-based science center exhibits. Science Education, 88(Suppl. 1), S34-S47.

Perry, D. L. (1989). The creation and verification of a development model for the design of a museum exhibit. (Doctoral dissertation, Indiana University, 1989). Dissertation Abstracts International, 50, 3296.

Phelan, P., Davidson, A., Cao, H. T. (1993). Students' multiple worlds: Negotiating the boundaries of family, peer, and school cultures. Anthropology and Education Quarterly, 22, 224-250.

Pilot, A., \& Bulte, A. M. (2006). The use of 'context' as a challenge for the chemistry curriculum: Its successes and the need for further development and understanding. International Journal of Science Education, 28(9), 1087-1112.

Porter, C., \& Parvin, J. (2009). Learning to love science: Harnessing children's scientific imagination. A report from the Chemical Industry Education Centre, University of York. Retrieved August 5, 2009 from http://wwwstatic.shell.com/static/gbr/downloads/responsible_energy/ro1427_ses_report.p $\underline{\mathrm{df}}$

Reiser, R.A., Williamson, W., \& Suzuki, K. (1988). Using “Sesame Street” to facilitate children's recognition of letters and numbers. Educational Technology Research and Development, 36, 15-21.

Rennie, L. J. (2006, August). The community's contribution to science learning: Making it count. ACER Research Conference 2006, Boosting science learning - What will it take? Conference Proceedings (pp. 6-11). Canberra, Australia: Australian Council for Educational Research.

Rennie, L. J. (2007). Learning science outside of school. In S. K. Abell \& N. G. Lederman (Eds.), Handbook of research on science education (pp. 125-167). Mahwah, NJ: Lawrence Erlbaum Associates.

Rennie, L. J., \& Howitt, C. (2009). “Science has changed my life!” Evaluation of the Scientists in Schools Project (A report prepared for CSIRO.) Canberra, Australia: Department of Education, Employment and Workplace Relations. (Retrieved November 25, 2009 from http://www.scientistsinschools.edu.au/evaluation.htm

Rennie, L. J., \& McClafferty, T. P. (1996). Science centres and science learning. Studies in Science Education, 27, 53-98.

Rennie, L. J., \& Stocklmayer, S. M. (2003). The communication of science and technology: Past, present and future agendas. International Journal of Science Education, 25, 759-773.

Rennie, L. J., \& Williams, G. F. (2002). Science centres and scientific literacy: Promoting a relationship with science. Science Education, 86, 706-726.

Rennie, L. J., \& Williams, G. F. (2006). Communication about science in a traditional museum: Visitors' and staff's perceptions. Cultural Studies of Science Education, 1, 791-820.

Research Councils UK. (2002). Dialogue with the public: Practical guidelines. London: Research Councils UK.

Roberts, D. A. (2007). Scientific literacy/science literacy. In S. K. Abell \& N. G. Lederman (Eds.), Handbook of research on science education (pp. 729-780). Mahwah, NJ: Lawrence Erlbaum Associates. 
Rockman, Et Al. (1996). Evaluation of Bill Nye the Science Guy television series and outreach. San Francisco. Retrieved January 23, 2009, from http://www.rockman.com/projects/topics/tvRadio.php

Rose, C. (2003). How to teach biology using the movie science of cloning people, resurrecting the dead, and combining flies and humans. Public Understanding of Science, 12, 289-296

Ryder, J. (2001). Identifying science understanding for functional scientific literacy. Studies in Science Education, 36, 1-44.

Sadler, W. J. (2006). Evaluating the short and long-term impact of an interactive science show. Unpublished Master's thesis. The Open University, Milton Keynes, United Kingdom.

Scanlon, E., Jones, A., \& Waycott, J. (2005). Mobile technologies: Prospects for their use in learning in informal science settings. Journal of Interactive Media in Education, 25, 1-10.

Schwartz, S. E. O., \& Noam, G. G. (n.d.). Informal science learning in afterschool settings: A natural fit? Retrieved February 15, 2009 from http://www.informalscience.org/researches/Schwartz abd Noam Commissio ned_Paper.pdf

Schwarz, E., \& Stolow, D. (2006). Twenty-first century learning in afterschool. New Directions for Youth Development, 110, 81-99.

Segall, A. E. (2007, September). Science fiction in engineering instruction: The final frontier? Proceedings of the International Conference on Engineering Education - ICEE 2007, Coimbra, Portugal. Retrieved February 15, 2009 from http://icee2007.dei.uc.pt/proceedings/papers/434.pdf

Semper, R. J. (1990). Science museums as environments for learning. Physics Today, 43(11), 50-56.

Sjøberg, S., \& Schreiner, C. (2005). How do learners in different cultures relate to science and technology? Results and perspectives from the project ROSE (the Relevance of Science Education). APFSLT: Asia-Pacific Forum on Science Learning and Teaching, 6, 1-16.

Stocklmayer, S. M., \& Gilbert, J. K. (2002a). New experiences and old knowledge: Towards a model for the public awareness of science. International Journal of Science Education, 24, 835-858.

Stocklmayer, S., \& Gilbert, J. K. (2002b). Informal chemical education. In: J. K. Gilbert, O. De Jong, R. Justi, D. F. Treagust, \& J.H. Van Driel (Eds.), Chemical education towards research-based practice (pp. 143-164). Dordrecht, The Netherlands: Kluwer.

Tunnicliffe, S. (1996). The relationship between pupils' age and the content of conversations generated at three types of animal exhibits. Research in Science Education, 26, 461-480.

Tunnicliffe, S. D., Lucas, A. M., \& Osborne, J. (1997). School visits to zoos and museums: A missed educational opportunity. International Journal of Science Education, 19, 1039-1056.

Turney, J. (2006, $14^{\text {th }}$ December). What's special about the best popular science books? Nature, 444, 819-20.

Turney, J. (2001). More than story-telling - reflecting on popular science. In S. M. Stocklmayer, M. M. Gore, \& C. Bryant, (Eds.). Science communication in theory and practice (pp. 47-62). Dordrecht, The Netherlands: Kluwer.

Twenty First Century Science. (2008a). Twenty First Century Science. The University of York Education Group. Scientific Literacy. Retrieved February 22, 2009, 
from http://www.21stcenturyscience.org/rationale/scientificliteracy,903,NA.html

Venville, G., Wallace, J., Rennie, L. J., \& Malone, J. (2002). Curriculum integration: Eroding the high ground of science as a school subject. Studies in Science Education, 37, 43-84.

Welch, W. W., \& Walberg, H. J. (1967). A national experiment in curriculum evaluation. American Educational Research Journal, 38, 373-383.

Wellington, J. (1990). Formal and informal learning in science: The role of interactive science centres. Physics Education, 25, 247-252.

White, R. T. (1994). Dimensions of content. In P. Fensham, R. F. Gunstone \& R. T. White (Eds.), The content of science (pp. 255-262). London: Falmer Press.

Wikepedia (2009). Extract from Second Life, http://en.wikipedia.org/wiki/Second_Life, retrieved 9.12.2009. 


\section{Appendix: Outline of a teaching and learning module on buoyancy.}

\begin{tabular}{|c|c|}
\hline Section 1: Introduction & Assessment and Teacher Notes \\
\hline $\begin{array}{l}\text { Initial engagement: Using the media } \\
\text { Watch the movie Titanic and assess the imagery of the accident, } \\
\text { the sinking and the overall explanations about the science. } \\
\text { Preliminary Exploration: A hands-on workshop provided by } \\
\text { the Science Centre } \\
\text { Workstation experiments include different floating and sinking } \\
\text { experiments, including objects of the same material, one which } \\
\text { floats and one which sinks and an experiment to show what } \\
\text { happens to the level of water when you sink or float something in } \\
\text { it. } \\
\text { Teacher Demonstration: } \\
\text { Models of matter - e.g. students to be solids, liquids, gases. }\end{array}$ & $\begin{array}{l}\text { Assessment } \\
\text { Students begin a journal. Students } \\
\text { make notes in their journal explaining } \\
\text { - what happened } \\
\text { - what they understand to be } \\
\text { happening } \\
\text { Teacher note: } \\
\text { From student recorded understandings, } \\
\text { any misconceptions should be clear. }\end{array}$ \\
\hline Section 2: Beginning Ideas & \\
\hline $\begin{array}{l}\text { Force (Teacher-led discussion) } \\
\text { What is it? Action- reaction ideas and demonstrations. Newton's } \\
\text { Third Law and force pairs. } \\
\text { Buoyancy Show: To sink or not to sink. (Interactive outreach } \\
\text { from the Science Centre) } \\
\text { Address misconceptions about fluids. } \\
\text { Compressibility of fluids. Water rockets. Pressure at a depth. The } \\
\text { origin of buoyancy. Why some things float and others sink. } \\
\text { Archimedes' Principle, and the history of Archimedes’ problem, } \\
\text { etc. } \\
\text { Use of media and discussion (Teacher-led) } \\
\text { Research and discuss deep sea creatures (if local museum can help } \\
\text { here, that is a bonus). } \\
\text { Scuba diving techniques. The 'bends'. Students as a knowledge } \\
\text { resource here. }\end{array}$ & $\begin{array}{l}\text { Communication - literacy } \\
\text { Students could research the story of } \\
\text { Archimedes and write about it. What } \\
\text { else did he do? }\end{array}$ \\
\hline $\begin{array}{l}\text { Design and evaluation: Making Cartesian Divers (student-led). } \\
\text { Students to locate designs on the web, test and evaluate. Rationale: } \\
\text { an engaging toy and a very important demonstration of the } \\
\text { buoyancy principle. }\end{array}$ & $\begin{array}{l}\text { Assessment } \\
\text { Effective design and evaluation }\end{array}$ \\
\hline Section 3: Guided Inquiry & \\
\hline $\begin{array}{l}\text { Pressure in the atmosphere (Science Centre as a resource) } \\
\text { Students can research demonstrations about the pressure of the air } \\
\text { and show them to the rest of the class. Their choice of }\end{array}$ & $\begin{array}{l}\text { Assessment } \\
\text { Presentation skills, explanations, use of } \\
\text { props }\end{array}$ \\
\hline
\end{tabular}




\begin{tabular}{|c|c|}
\hline $\begin{array}{l}\text { demonstration is up to them. } \\
\text { Examples: } \\
\text { The egg in a bottle } \\
\text { Breaking a ruler - a sheet of newspaper traps a ruler } \\
\text { The Magdeburg Spheres - the plumber's aid } \\
\text { Why do tea pot lids have gaps in them? } \\
\text { The crushing can }\end{array}$ & $\begin{array}{l}\text { Useful to have an 'assessor' from the } \\
\text { Science Centre to make it more } \\
\text { relevant. Excellent if the best efforts } \\
\text { could subsequently 'busk' at the Centre } \\
\text { with their demonstrations. }\end{array}$ \\
\hline $\begin{array}{l}\text { Boats: Group Design competition. (Student-led) } \\
\text { Design and make a boat out of paddle pops and glue, or out of } \\
\text { aluminium foil, to float under increasing loads such as a series of } \\
\text { marbles. The rules should be devised by the students, negotiated } \\
\text { and agreed beforehand. }\end{array}$ & $\begin{array}{l}\text { Assessment: } \\
\text { Students should identify the steps in the } \\
\text { design process, recording group } \\
\text { discussions/decisions and why the final } \\
\text { model is selected. } \\
\text { Peer Assessment may be incorporated } \\
\text { into the competition }\end{array}$ \\
\hline $\begin{array}{l}\text { Research: } \\
\text { Investigate: What powers a boat? (Paddle steamers, steamboats, } \\
\text { rowing boats, container ships, sailboats, etc.) } \\
\text { Investigate: The importance of river boats in Australian history }\end{array}$ & $\begin{array}{l}\text { Assessment } \\
\text { A presentation, either by individuals or } \\
\text { as a group, with visual aids }\end{array}$ \\
\hline Section 4: Culminating Activities & \\
\hline $\begin{array}{l}\text { 1. Designing a boat } \\
\text { Guest speaker: A boat designer describes current design } \\
\text { considerations of boats (e.g. Tasmanian wave-piercing } \\
\text { catamarans) and future trends. This talk is important for the final } \\
\text { stage of design: }\end{array}$ & \\
\hline $\begin{array}{l}\text { My perfect boat } \\
\text { Students should research and design the interior and exterior of a } \\
\text { sea-going boat which meets their stated goals for the purpose of } \\
\text { the boat, which conforms to expectations about boat travel in the } \\
21^{\text {st }} \text { Century and which, when "holed" or capsized accidentally, } \\
\text { will not pollute the ocean. }\end{array}$ & $\begin{array}{l}\text { Assessment } \\
\text { In assessing the boat designs, it is very } \\
\text { important to allow for gender } \\
\text { differences (An excellent paper about } \\
\text { this issue with respect to boat design is: } \\
\text { Murphy, P.F. (1996). Assessment } \\
\text { practices and gender in science. In } \\
\text { L.H.Parker, L.J. Rennie and B.J. Fraser } \\
\text { (Eds), Gender, science and } \\
\text { mathematics: Shortening the shadow. } \\
\text { Dordrecht, Netherlands: Kluwer } \\
\text { Academic. }\end{array}$ \\
\hline $\begin{array}{l}\text { 2. Collaborative project: Ocean problems; Boats as a source of } \\
\text { marine pollution } \\
\text { Guest speaker: A researcher engaged in marine pollution } \\
\text { investigations explains the issues: oil spills, invasive sea creatures } \\
\text { that are brought in by boats, chemical pollution. } \\
\\
\text { If at all possible, this researcher engages the students in } \\
\text { collaborative projects gathering real data. A choice of projects } \\
\text { would further enhance this activity. }\end{array}$ & $\begin{array}{l}\text { Assessment } \\
\text { Assessment should focus on both } \\
\text { knowledge and research/evaluation } \\
\text { outcomes. }\end{array}$ \\
\hline & \\
\hline
\end{tabular}


How does this pollution affect my community? How does it affect the State of Tasmania? Australia? The world? What should be done? Can an individual affect outcomes?

\section{ELECTRONIC RESOURCES}

Indicative only - there are many of these

The Vasa: http://www.abc.se/ m10354/publ/vasa.htm The Exxon Valdez Oil Spill:

http://response.restoration.noaa.gov/spotlight/spotlight.html A typical interesting buoyancy site:

http://www.pbs.org/wgbh/nova/lasalle/buoyancy.html

The Tasmanian Connection: Wave-piercing catamarans http://stott.customer.netspace.net.au/devilcat.htm and http://www.incat.com.au/

Students can check out: The Titanic; Icebergs; Scuba Diving; The Mary Rose; Archimedes; Floating continents; Deep sea creatures; Marine pollutants, etc. 
Table 1.

Wellington's (1990) Comparison of Informal and Formal Learning

\begin{tabular}{ll}
\hline Informal learning & Formal learning \\
\hline Voluntary & Compulsory \\
Haphazard, unstructured, unsequenced & Structured and sequenced \\
Non-assessed, Non-certificated & Assessed, certificated \\
Open-ended & More closed \\
Learner-led, learner centred & Teacher-led, teacher-centred \\
Outside of formal settings & Classroom and institution based \\
Unplanned & Planned \\
Many unintended outcomes (outcomes more & Fewer unintended outcomes \\
difficult to measure) & \\
Social aspect central, e.g. social interactions & Social aspect less central \\
between visitors & \\
Low “currency” & High “currency” \\
Undirected, not legislated for & Legislated and directed (controlled) \\
\hline
\end{tabular}


Table 2.

Martin’s (2004) Comparison of Informal and Formal Learning

Informal Learning Learning in Westernized School Settings

Occurs in the course of mundane adult activities Emphasizes universalistic values, criteria, in which the young take part according to their and standards of performance.

abilities.

Occurs in families; expectations are in terms of What is being taught is more important than who a person is not what was accomplished. who is doing the teaching.

Fosters traditionalism. May represent a culture that denigrates the indigenous culture.

Fuses emotional and intellectual domains. Emphasizes language; language occurs out of context.

Is strongly observational, participatory. $\quad$ Emphasizes mastering symbol systems.

Occurs where meaning is intrinsic to context. Introduces new subjects, unknown history, and physical universe not derived from senses. 
Table 3.

Seven Features Which Add to the Success of Popular Science Writing (from Meyer, 2005, pp. 154-155)

\begin{tabular}{ll}
\hline Feature & Description \\
\hline The topic & A topic of universal appeal and relevance (such as cosmology or \\
& genetics) or a topic at the 'cutting edge' of science (such as \\
biochemistry, particle physics or chaos theory). A focus on & multidisciplinary topics or those that involve faith or religion. \\
& Avoidance of jargon; necessary technical terms explained in context; \\
scientific ideas not over-simplified; the use of metaphor, analogy and & anthropomorphism. \\
& Scientific facts woven into a narrative. \\
The presence of people in the story. (Often there were & autobiographical or biographical elements.) \\
People & A conversational tone with avoidance of the passive voice. \\
Tone & A high level of readability. \\
Readability & Passion, enthusiasm, flair and excitement, with use of fictional \\
Writing style & techniques.
\end{tabular}


Table 4.

Adults' Sources of General Science Information (Falk, 2009)

\begin{tabular}{lcc}
\hline Source of information & 2000 (\% responding) & 2009 (\% responding) \\
\hline Internet & 10 & 87 \\
Television & 74 & 67 \\
Books and magazines (not school- & 76 & 63 \\
related) & 55 & 45 \\
Family and friends & 65 & 41 \\
Science museums, zoos, aquaria & 57 & 37 \\
"on the job” & 68 & 34 \\
School courses & 31 & 25 \\
Radio and educational tapes & Not asked & 12 \\
Hobby club or group & & \\
\hline
\end{tabular}


Table 5. Summary of Factors Found to Encourage Learning in the Informal Sector

\begin{tabular}{ll}
\hline Factor & Comment \\
\hline $\begin{array}{l}\text { Affective Factors } \\
\text { Providing for free choice }\end{array}$ & $\begin{array}{l}\text { Some sense of ownership and control is clearly appealing in the } \\
\text { context of science learning. }\end{array}$ \\
$\begin{array}{l}\text { Internally driven and } \\
\text { challenging }\end{array}$ & $\begin{array}{l}\text { Motivation on the part of the student is a powerful and essential } \\
\text { and mirror some aspects of the nature and processes of science. }\end{array}$ \\
$\begin{array}{l}\text { Curiosity and surprise have also been identified as adding to } \\
\text { positive outcomes. }\end{array}$ \\
$\begin{array}{l}\text { Encouraging wonder, delight } \\
\text { and awe }\end{array}$ & $\begin{array}{l}\text { Science is essentially about the delight of discovery. The sense of } \\
\text { wonder and awe is frequently stressed in informal programmes, }\end{array}$ \\
$\begin{array}{l}\text { Entertaining, interesting, } \\
\text { enjoyable }\end{array}$ & $\begin{array}{l}\text { Engagement is a key factor in encouraging students to study } \\
\text { science. This is sustained only if there is a measure of interest and } \\
\text { enjoyment embedded in the activity. }\end{array}$ \\
\hline
\end{tabular}

Factors Relating to Learning Science

Holistic

Reductionist science is less accessible than multidisciplinary approaches in a real context.

Useful, powerful and transferable knowledge

Constructive inquiry learning encourages transferability recognizing students' prior knowledge and experiences. Recent discoveries add interest.

Strongly emphasising narrative

Narratives may take many forms but should encourage personal meaning-making.

Presenting science which is simply explained, jargon-free "Science as a story" is helpful, again emphasising the importance and in the active voice of narrative. Analogies and models enhance understanding.

Factors Related to Learning about Science

Facilitating social and community interaction

Presenting science as messy, human and exploratory in nature, addressing real and current problems
On the theme of relevance, if connections to community are overtly made, the point of the activity is more easily understood.

Facilitating border crossing is very important.

That science is a human endeavour, involving real people, is critical to interest and engagement. Scientific processes and the Nature of Science should be emphasized.

\section{Factors Related to Doing Science}

Facilitating inquiry-based science

Involving real projects with real outcomes
Real contexts and real data are important for successful inquiry learning. Interactivity encourages experimentation. Such activities are intrinsically engaging and build confidence.

The presence of real scientists in these projects enhances their importance for students. 